University of Nebraska - Lincoln

DigitalCommons@University of Nebraska - Lincoln

$6-2020$

\title{
Life of a Peruvian art collector: Guillermo Schmidt Pizarro and the fostering of public collections of pre-Hispanic art in the first half of the 20th century
}

Carolina Orsini

Anna Antonini

Follow this and additional works at: https://digitalcommons.unl.edu/pctviii

Part of the Art and Materials Conservation Commons, Fiber, Textile, and Weaving Arts Commons, Indigenous Studies Commons, Latin American Languages and Societies Commons, Museum Studies Commons, and the Other History of Art, Architecture, and Archaeology Commons

This Article is brought to you for free and open access by the Centre for Textile Research at DigitalCommons@University of Nebraska - Lincoln. It has been accepted for inclusion in PreColumbian Textile Conference VIII / Jornadas de Textiles PreColombinos VIII (2019) by an authorized administrator of DigitalCommons@University of Nebraska - Lincoln. 


\title{
Life of a Peruvian art collector: Guillermo Schmidt Pizarro and the fostering of public collections of pre-Hispanic art in the first half of the $20^{\text {th }}$ century
}

\author{
Carolina Orsini and Anna Antonini \\ Museo delle Culture, Milano, Italia \\ Corresponding author: Carolina Orsini, Museo delle Culture, Via Tortona 56, 20144, Milano, Italia. Carolina.Orsini@comune.milano.it
}

\begin{abstract}
Guillermo Schmidt Pizarro was a famous collector of Peruvian origins, active in Europe and the United States beginning in the early twentieth century. He traded numerous pre-Hispanic and colonial artifacts to the most important museums of the time. The focus of this preliminary work is to trace his biography and the sales he dealt with over thirty years of activity. Thanks to provenance information, the authors have been able to sometimes "virtually build up" fragments of textiles that he scattered among diverse public and private institutions. The importance of this research is consistent with the efforts of museums to trace the origin of every artifact in their collections.
\end{abstract}

Keywords: Guillermo Schmidt Pizarro, Andean archaeology, ethnographic museums, history of collections, provenance, art dealers

\section{Resumen}

Guillermo Schmidt Pizarro fue un famoso coleccionista de origen peruano activo en Europa y en los Estados Unidos desde la primera mitad del siglo XX. Él estuvo en contacto con los museos más importantes de su época, ofreciéndoles numerosos artefactos prehispánicos y coloniales. El enfoque del presente trabajo preliminar es trazar su biografía y las ventas en las cuales estuvo involucrado durante más de treinta años de actividad. Gracias a los datos de provenance, las autoras en algunos casos han podido "reconstruir de forma virtual" los fragmentos de textiles que él ha disperso entre diversas instituciones públicas y particulares. La importancia de esta investigación queda en respaldar los esfuerzos de los museos para trazar el origen de cada artefacto en sus colecciones.

Keywords: Guillermo Schmidt Pizarro, arqueología andina, museos etnográficos, historia de colecciones, provenance, comerciantes de arte

\section{Resumé}

Guillermo Schmidt Pizarro était un célèbre collectionneur originaire du Pérou qui opéra en Europe et aux États-Unis au début du XX $\mathrm{X}^{\mathrm{e}}$ siècle. Il eut des rapports étroits avec les musées les plus importants de son époque auxquels il procura plusieurs artefacts préhispaniques et coloniaux. Le but de ce travail préliminaire est de tracer sa biographie et les ventes dont il s'occupa pendant plus de trente ans d'activité. Grâce aux informations de provenance, les auteures ont parfois pu « reconstruire virtuellement » les fragments de tissus dispersés parmi diverses institutions publiques et privées. L'importance de cette recherche constitue une contribution offerte aux musées pour retracer l'origine des artefacts de leurs collections.

Mots-clés: Guillermo Schmidt Pizarro, archéologie andine, musées ethnographiques, histoire des collections, provenance, marchands d'art 


\section{Introduction}

Beginning in the 1920's, Guillermo Schmidt Pizarro (1880 - 1964) (also here referred to as S.P.), a Peruvian antique dealer whose biography is still partly unknown, managed to sell a large number of Andean artifacts from different periods and types to over thirty museums and private collectors across the United States and Europe.

Thanks to informal relationships over the past five years with museums that house artifacts sold by Schmidt Pizarro, we have been able to uncover detailed information about this art dealer and his heritage in order to understand the methods, criteria and purposes by which he managed to supply a large amount of pre-Hispanic artifacts to Europe and the United States. In this preliminary essay, we trace his biography as a first step in tracking his collection.

This essay raises more questions than answers, yet stands as a first step toward understanding what type of Andean materials circulated in the antique market in Europe and the United States from the beginning of the $20^{\text {th }}$ century until the 1960's. This article seeks to shed light on the way the antiquities market was run, how power and economic strengths were stimulated through the sale of artifacts, and how the availability of specific artifacts and their circulation in exhibitions and sales affected taste regarding what was at the time considered "important" to collect in Europe and the United States.

Tracing Schmidt Pizarro's personal history and his way of maneuvering geographically is therefore crucial. His life experience, much like that of other art dealers of the time, his background and his contacts have been fundamental to the dissemination of pre-Columbian works, especially when considering the large quantity of artifacts that he managed to sell and the close ties he established with the principal museums of that time. Paradoxically, his history has remained for a long time in the shade, despite the fact that Schmidt Pizarro had also taken on public tasks besides his "work" as an antique dealer. Another key element to understand the mechanisms that ran the Andean art market of the time is the sales strategy endorsed by Schmidt Pizarro, which was certainly shared with other art dealers of the time, the principal features of which will be tackled in the final part of this article. Finally, the authors shall deal with the circulation of these artifacts through art exhibitions.

A great part of our research focuses on the textiles collected by Schmidt Pizarro. Notwithstanding his trade in all types of pre-Hispanic and colonial materials, textiles played a primary role in his activities. This preference is probably due not only to his taste, but also to the ease in transporting textiles, fundamental for the tireless traveler he was, and to the potential high revenues that he could earn from dividing (or even cutting?) the fabrics to then sell them parceled out to diverse museums (fig. 1). From the point of view of the authors, the study of textiles has enabled us to track his movements, following an imaginary Ariadne's thread that Schmidt Pizarro left unintentionally behind him, ${ }^{1}$ searching for fragments of the original textiles across the various museums, and thus being able to connect episodes and parts of his life. In fact, another purpose of this work, which will only be marginally tackled in this article and which will constitute an independent study, is the tracking of each textile, so parceled out that today it may belong to a number of diverse collections.

\section{About Objects Biography}

One of the approaches endorsed today by museums is that they are no longer a place where something is simply exhibited or conserved, but a place where objects can contribute to the construction of a community and personal growth (Weil 1999). The path leading to this assumption has been quite long. The commitment of museums toward the public begins from better understanding their own history so as to be able to convey it more honestly and openly to visitors and eventually turn it into a place of dialogue. Therefore, today, equal attention is paid to the material an object is made of, and to the technical and functional features of an object as an igniter of processes, at least since this phenomenon has been theorized by Kopytoff (1986) and many other scholars after him (e.g. Gosden - Marshall 1999).

Understanding the role played by an artifact as an igniter of social, legal, political and economic processes is achieved through tracing the history of the artifact and the multiple functions that it has assumed during time. Tracking the life of an artifact is today a vital element of museum research. This task entails a fundamental first step: tracing the biography of the people that have collected the artifacts (Hill 2012). This task is quite challenging when the origin of artifacts is unknown, as well as their collection history, because they have not been gathered during scientific expeditions or excavations, but through the activity of art dealers

1. As regards the tracing of collections, our thanks go to those museums that, besides their traditional catalogues, have published databases online which can be freely consulted. When the collection origin is not explicit in these catalogues, we start from works comparable to others previously identified. In some cases, thanks to archival documents, we have traced the probable origin of Schmidt Pizarro's collection. It has been a very long process that we hope to continue, thanks to the valuable collaboration of our peers. 

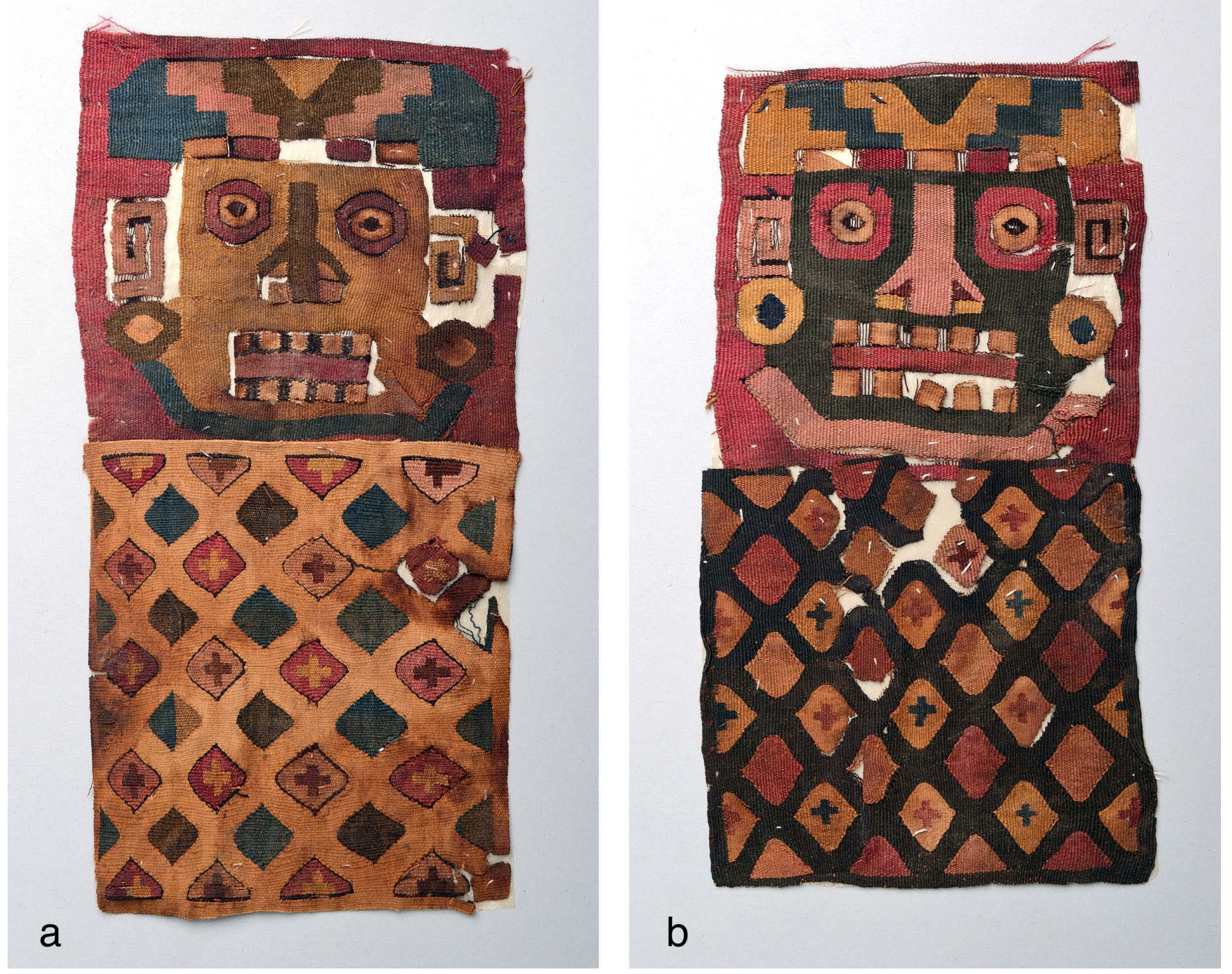

Figure 1a-b. Two emblematic tapestry fragments of faces and diamond motifs from the Schmidt Pizarro collection now at Mudec (South Coast of Peru, A.D. 500 - 1000). Inv. PAM 00143 (10,5X21cm) and PAM 00145 (11,5X23cm). Courtesy Mudec - Museo delle Culture, Milan. Other pieces of the same textile with Schmidt Pizarro provenance are conserved in: British Museum (Am1933,-..10.b, Am1933,-.10.c); Brooklyn Museum of Art (34.559.1 a-d); Boston Museum of Fine Arts (31.701-4); Castello d'Albertis (C.A.1483, C.A. 1493-4); Museum für Gestaltung Zürich (KGS-1952-0012); Rietberg (RPB 1303 a-d); Textile Museum (91.119 a-d); Welt Museum (98.243). See also the following pieces probably of the same garment but without an explicit Schmidt Pizarro provenance: Abegg Foundation (1147 a-d); Joseph and Anni Albers Foundation (1994.16.6); Koninklijke Musea voor Kunst en Geschiedenis (AAM ooo5881-4); Metropolitan Museum of Art (33.149.85b, 33.149.86 a-b); MuCiv - Museo preistorico etnografico Luigi Pigorini (182896); Museum der Kulturen Basel (92.96, 92.97); Rhode Island School of Design (50.383, 50.384); Royal Museums of Art and History (AAM 5881-5884); Victoria and Albert Museum (T.75-1933).

having scarce (or no) interest in documenting their work. In this case, the "biography" of an artifact is compromised in two ways: when cut into smaller fragments, its original features can hardly be tracked, likewise its place of origin or original provenience. The artifact's recent history is obscure and problematic, as well. Sometimes the denied history of people and things is the fruit of mere carelessness, sometimes it is the outcome of a well devised project aimed at willingly erasing stories of abuses, robberies or illegal actions (Thebele 2018 and quoted bibliography).

Today, modern museum ethics ${ }^{2}$ impose a radical change of trend, triggered also by several legal actions that have 
been filed by governments on the matter of cultural heritage over the last fifty years. ${ }^{3}$ Our aim is to trace the biography of an art collector as a first step in tracking the history of the objects that he collected. This is necessary in order to assess the legitimacy (or not) of his collection. Moreover, in trying to re-connect the fragments of his collection, we hope to give new instruments to other the researchers in order to repair the damage caused by this type of collecting.

This study is grounded in the search across secondary and informal sources, since the primary objective of Schmidt Pizarro's collection, likewise that of many other art dealers of the time ${ }^{4}$, was simply to get a revenue from his sales, by selling as many specimens as possible. The hints that he gave from time to time with regard to his "supplying" sources and to the places where he collected these objects are seldom reliable, because there was no scientific purpose in the descriptions that he left, but only the willingness to increase the value of "goods" being sold, perhaps highlighting their "rare" nature. Yet, as we will see, Schmidt Pizarro was undoubtedly a cultivated man, with many acquaintances among the scholars of the time (see below). His contradictory approach is not surprising and is a product of the attitudes in vogue at the time.

Being unable to rely on the history provided by Schmidt Pizarro himself, we have traced his biography step by step through the history of his collection, beginning with the correspondence made available to us by colleagues in several museums in Europe and the United States. Our research also included legal documents, such as deeds of sale, payment slips, invoices, ship passenger lists, lists of immigration or transit registers in the ports of Ellis Island (New York), San Francisco and Southampton/Plymouth (UK / 1900 - 196o); newspapers, magazines, parish church documents and registers of baptism.

\section{An Adventurous Life}

The biography of Guillermo Schmidt Pizarro is still very uncertain, especially in regard to the early years of his life. He had a long life, full of adventure, mostly spent traveling and frequenting environments linked to art and diplomacy. He was born in Tacna, Peru on September 27, 1880, ${ }^{5}$ the son of Federico Guillermo Schmidt (born in Osnabruck, Germany, and baptized a few days before his marriage celebrated in Tacna in 1876) ${ }^{6}$ and Mercedes Pizarro. Guillermo Schmidt Pizarro had two younger brothers, Federico Carlos, born in 1886,7 of whom we were unable to find other information, and Juan Oscar, who was born in $1883^{8}$ and died in Lima in $1967 . .^{9}$ The latter was vice-consul of Peru in Germany in the 1920's: he appears in the yearly Hamburg directory of 1922 and $1923 .{ }^{10}$ We also found Oscar referred to as "prok.", perhaps an agent in a company with interests in saltpeter mines, the H. Folsch \& Co. ${ }^{11}$ Guillermo died on January 20, 1964 in San Isidro, Lima (Fig. 2). ${ }^{12}$

The many relationships with Germany can be explained by his paternal origins. It is probable that the children maintained bonds with their father's home country and spoke German (Oscar married Ilse Achenbach, ${ }^{13}$ of German nationality, in Hamburg).

As is known, Chile was an important area of German immigration and the territory of Tacna was long disputed between Chile and Peru. Between the end of the Pacific War (1883) and 1929, Tacna was Chilean. Today it is still a few

3. The last European legislation effort is European Parliament Resolution of 17 January 2019 on cross-border restitution claims of works of art and cultural goods looted in armed conflicts and wars (2017/2023). See also Report A8-0465/2018 by Pavel Svoboda of 13.12.2018, https:// www.europarl.europa.eu/doceo/document/A-8-2018-0465 EN.pdf?redirect.

4. Other dealers or even museum curators cut textiles for different reasons. See, for example, the "doubletten” case documented by Bjerregaard (2001).

5. Register of baptisms, parish of San Pedro in Tacna, 1880. The data corresponds with a declaration to the US immigration office of Ellis Island and is found in the ship manifests of passenger arrivals in the years between 1911 and 1956.

6. Register of baptisms, parish of San Pedro in Tacna, 1876.

7. Register of baptisms, parish of San Pedro in Tacna, 1886.

8. Register of baptisms, parish of San Pedro in Tacna, 1883.

9. “Municipalidad de San Isidro" Peru. Lima, Civil records (1884-1996), Archivo General de la Nación, 1967, p.363.

10. Hamburger Adressbuch 1922, 1923, http://agora.sub.uni-hamburg.de/subhh-adress/digbib/start, retrieved 20.05.2019.

11. After the Saltpeter War in 1883 , Chile gained the monopoly of this precious raw material. Many companies settled in that difficult region that also included the southern portion of present-day Peru. During the Pacific War, the Hamburg merchant Hermann Conrad Johannes Fölsch established the company "Fölsch \& Martin" in Valparaiso active in the export of saltpeter from Chile. At the same time, he established the shipping company "H. Fölsch \& Co.” in Hamburg to import saltpeter. The company bankrupted after August 1921, after an accident.

12. The death is registered in "Municipalidad de San Isidro" Peru. Lima, Civil records (1874 - 1996), Archivo General de la Nación, 1964. The death date reported in Bernal Multon 2018 and in several online databases (National Museum of American Indian, British Museum) is 196o, but it is mistaken: this is also proved by the date of his latest sales, in the early sixties (see below).

13. Civil records (1884-1996), Archivo General de la Nación, 1941. Reports the deed of marriage celebrated in Hamburg in 1921. 


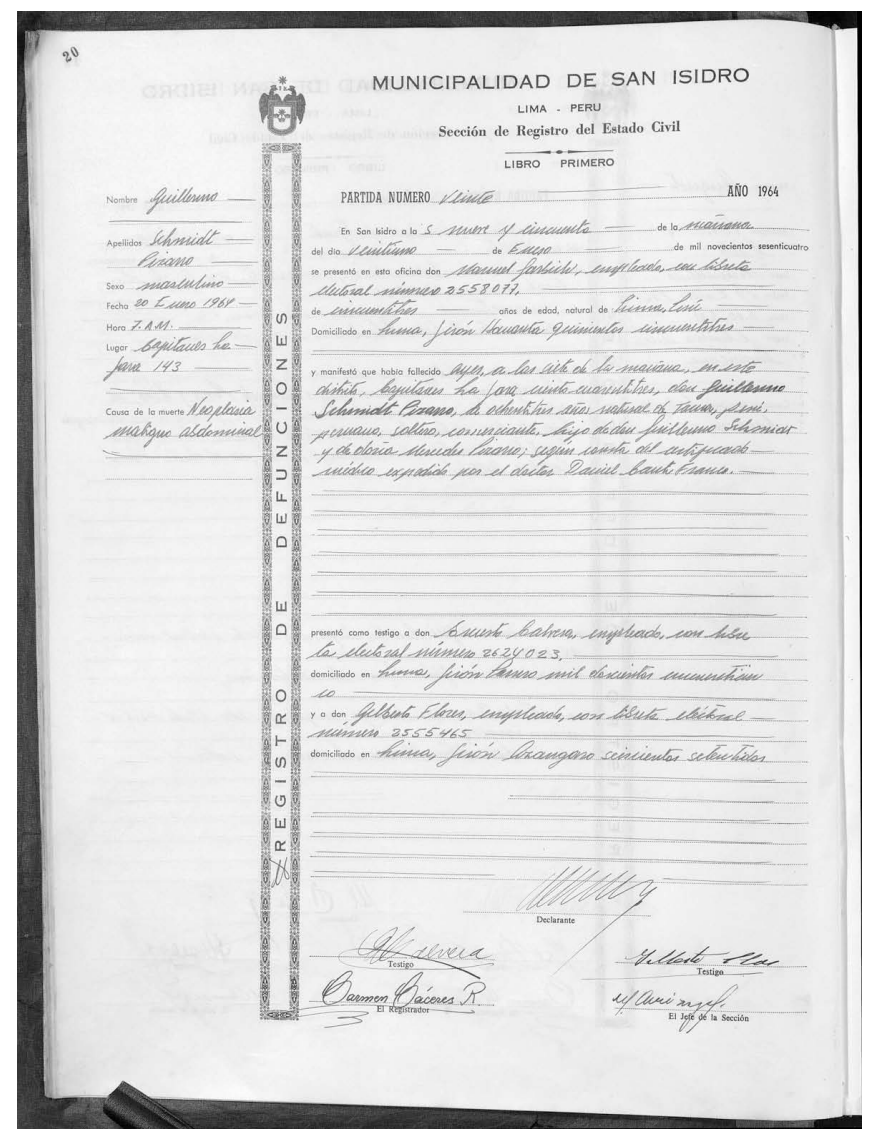

Figure 2. Death certificate of Guillermo Schmidt Pizarro. Courtesy Archivo General de la Nación, Lima.

miles from the border with Chile and it was a place of arrival for German immigrants in the nineteenth century (Hoerll 1910). The ties of the Schmidt Pizarro family with Chile are documented by Guillermo in the excerpt of a newspaper interview, probably El Mercurio. ${ }^{14}$ Guillermo is known to have been a resident of Iquique in $1909,{ }^{15}$ another disputed city that from 1884 became definitively Chilean, and in 1911 he lived in Santiago. ${ }^{16}$ His parents also lived in Iquique: his father until 1910 when he is presumed to have died, and his mother from $1911^{17}$ onward.
As of now, we have not been able to find any information relating to the education of either Oscar or Guillermo, even though they undoubtedly received a high level of education, given the positions they held in their future professional careers. Guillermo had some instruction on pre-Hispanic manufacturing techniques: Raoul D'Harcourt, ${ }^{18}$ in his famous book devoted to pre-Hispanic textiles, thanked Mr. Schmidt Pizarro of Lima for his help with images and information about textile techniques (1934: page VII). ${ }^{19}$ Subsequently, Guillermo wrote a short article on pre-Hispanic platería silversmithing (see below).

Apparently, Guillermo had no children and never married. In the immigration documents of Ellis Island, he always declared himself "S", or "single", and in the record of his brother's marriage, he declared himself soltero at the age of 61 . We only know of one image of Guillermo, but thanks to the extensive records of US Immigration, we know that he was very tall, over $6 \mathrm{ft}$, with brown hair and greenbrown eyes.

On several occasions, ${ }^{20}$ Guillermo declared himself to be a descendant, on his mother's side, of Francisco Pizarro, the famous conquistador of Peru: a fact that we have not presently verified. Apart from the veracity of the statement, this claim certainly allowed him to identify himself as a figure belonging to the elite and, consequently, with privileged access to objects of great artistic and historical value.

\section{Travels and Relations with Museums}

Guillermo Schmidt Pizarro began to travel as an adult. His first trips can be traced back to 1909 and 1911, voyages he made with his mother to England. In 1921, while they were residents of Valparaiso, ${ }^{21}$ he made another trip to Europe, once again accompanied by his mother. His first contacts with museums can be established beginning in the late 1920's. At the moment, there is still the question of how he supported himself before the age of 45 , when he began to sell the collection that he often referred to as belonging

14. Annex to the letter of February 16, 1946 sent by Schmidt Pizarro to Herbert Spinden, curator of the ethnographic section of the Brooklyn Museum (the Brooklyn Museum Archives, Director [02]. File \# 117. Spinden, Herbert J. (01 / 1939-12 / 1943).

15. Port of Ellis Island passenger manifest of the ship Santa Marta (Tropical Fruit Co.), May 4, 1911.

16. Port of Ellis Island passenger manifest of the ship Orinoco (unknown company), April 28, 1909.

17. Addresses of residence declared in the trips to New York of 1909 and 1911. In 1921, the mother declares herself widow Schmidt.

18. Born in 1879, Raoul D'Harcourt lived in Peru while he was working for the company Société Générale. The pre-Hispanic civilizations of Peru became the main focus of his studies, which he continued with his wife Margarite once he came back to Paris. In 1920, he began collaborating with the scholar Paul Rivet and became a prominent member of the Sociéte des Américanistes until his death, in 1971. See below for the relations between D'Harcourt and Pizarro.

19. Several pieces from the "Schmidt of Paris" collection appear in the same volume.

20. New Zealand Herald, 2 November 1935.

21. Incoming passenger manifest, port of Liverpool, May 1, 1921, ship Orcoma, Pacific Steam Navigation. 
"to his ancestors". ${ }^{22}$ The first information we collected relates to a sale of 74 objects to the Museum of Ethnography in Hamburg between the years 1926 and 1927. ${ }^{23}$ In August 1926, he gave 56 objects to the Ethnological Museum $(\mathrm{Mu}-$ seum für Völkerkunde) of Berlin, still declaring that he resided in Hamburg. ${ }^{24}$

In May 1928, he was in transit to New York on the ship "Santa Ana" originating from Valparaiso. It would seem that he had returned to South America and from there had left for the United States. Here, in December 1928, he sold some items to the famous antique dealer Joseph Brummer: ${ }^{25}$ a silver container ( $\mathrm{N} 2453$ ), and three Inca “embroideries" (NN $2454,2455,2456$ ). This is only the first of at least ten other transactions between the two antique dealers (for a total of 196 objects) made between May 1929 and October $1931 .^{26}$ The online catalog of the Metropolitan Museum of Art features two fragments of borders (31.20.2-31.20.1) entered in 1931 as a gift from George D. Pratt, ${ }^{27}$ but indicated as purchased from Joseph Brummer, who in turn had acquired them from Schmidt Pizarro. ${ }^{28}$ It is likely that some of the items sold to Brummer merged into Pratt's collection, and then arrived to the Metropolitan Museum but do not today appear in the online catalogue. Likewise, it is also possible that S.P. sold to Pratt without any trace of a record. Another possible proof is that some of the textiles belonging to the Metropolitan and catalogued as G.D. Pratt are apparently fragments of other textiles of Schmidt Pizarro origin, present in other museums (fig. 3a-b). ${ }^{29}$

Despite his intense commercial activity, in May 1930 Schmidt Pizarro was back in Chile, at the Hotel Crillon, as witnessed by the newspaper "La Nación" of May 3, 1930. On July 4, 1930, he landed again in Plymouth, probably intending to reinitiate sales to the major museums in Europe. It seems plausible that his returns to South America might have served to actually retrieve new items to sell, kept safely in the motherland. In 1930, he scored two of his most important sales.

In July, he sold a fabulous gold Nasca mask along with 21 other objects for 25,00o francs to the Musée du Trocadero in Paris. ${ }^{30}$ In November of the same year, in Madrid, he closed an important sale of 35 fabrics and objects from his collection, principally Nasca, Paracas and Supe, in addition to 13 colonial fabrics for a total of 9460 pesetas. ${ }^{31}$ In the documentation of the Museo Arqueológico Nacional in Madrid, there is a sort of rudimentary price list of the collection ${ }^{32}$ (fig. 4) that the antique dealer was willing to almost halve: from here we began to understand some of Schmidt Pizarro's sales strategies that will be a recurring practice.

22. Letter from Schmidt Pizarro to Nicodemi dated October 29, 1934, Dossier 49/1937 of the Education Section kept at the Citadel of the Archives (Cittadella degli Archivi) of the City of Milan; letter from Schmidt Pizarro to Underhill dated February 10, 1932 (CMA Archives). In several letters, he refers to the shared ownership with his brothers (the most direct proof is a letter from Schmidt Pizarro to Spinden dated November 16, 1946, The Brooklyn Museum Archives, Director [02]. File \# 117. Spinden, Herbert J. (01 / 1939-12 / 1943). See biographies of the cited scholars in the following pages.

23. The Museum of Ethnography in Hamburg suffered considerable damage during World War II and, unfortunately, the pre-Hispanic collection seems to have suffered enormous losses. We know that, in addition to Guillermo's materials, the museum purchased 917 objects from Chile, Africa and Oceania from the collection of his brother, the consul, see below.

24. Deed of Donation 901/1926, Ethnologisches Museum Archive, Staatliche Museen, Berlin.

25. Joseph Brummer (1883-1947) was a famous antique dealer of Hungarian origin. Together with his brothers Imre and Ernest, owned one of the most important art galleries in the world, with offices in New York and Paris dealing with objects from classical antiquity to art of the twentieth century. Since its inception in Paris in 1906, the Brummer brothers also focused on objects from Asia, Africa and America. He contributed to the construction of some of the largest US public and private collections including the Metropolitan Museum of Art (Brennan 2015, pp. 455-457).

26. The Brummer Gallery records (The Metropolitan Museum of Art): examination of technical files of works.

27. George Dupont Pratt (1869-1935). Descendant of oil magnate Charles Pratt, beyond his career was a philanthropist and sports enthusiast. A great lover of hunting and travel, he was the sponsor of various cultural institutes including the American Museum of Natural History and the Metropolitan Museum of Art (Allen Anderson 2019).

28. The exact wording is: Guillermo Schmidt y Pizarro, Peru and New York, until 1930; [Joseph Brummer, New York and Paris, 1930-1931]; George D. Pratt, Glen Cove, NY, until 1931. https://www.metmuseum.org/art/collection/search/308012?searchField=All\&amp;sortBy=relevance\&a $\mathrm{mp} ; \mathrm{ft}=\mathrm{schmidt}+$ pizarro\&amp;offset=o\&amp;rpp $=20$ \& pos $=5$ consulted on December 13, 2018.

29. For example, the fragments of Paracas borders from Metropolitan Museum of Art 33.149.9 and 33.149.7, which seem to be identical to PAM 135, 140 of the Mudec of Milan, respectively (purchase Schmidt Pizarro of 1934, see below), or even the rare fragment of Recuay fabric 30.16.7, which seems to be identical to a Schmidt Pizarro's Recuay fragment now kept at the Museo de América in Madrid (inv. 14525). As a caveat, to date the virtual "reconstruction" of fragments is based only on comparisons of photos and measurements.

30. Bernal Multon 2018: 16. These are objects with inv. 71.1930.49.1 - 21.

31. A descriptive note of the collection is in Vega 1933. Catalog of the Ibero-American collections of the Museum: nos. 14512, 14513, 14502, 14504, 14505, 14511, 14514, 14516, 14523, 14524, 14528, 14530, 14534, 14537, 14548, 14563, 14564, 14571, 14575, 14577, 14578, 14582, 14592, 14593, 146o5, 146o6, 14617, 14622, 14623, 14638. 

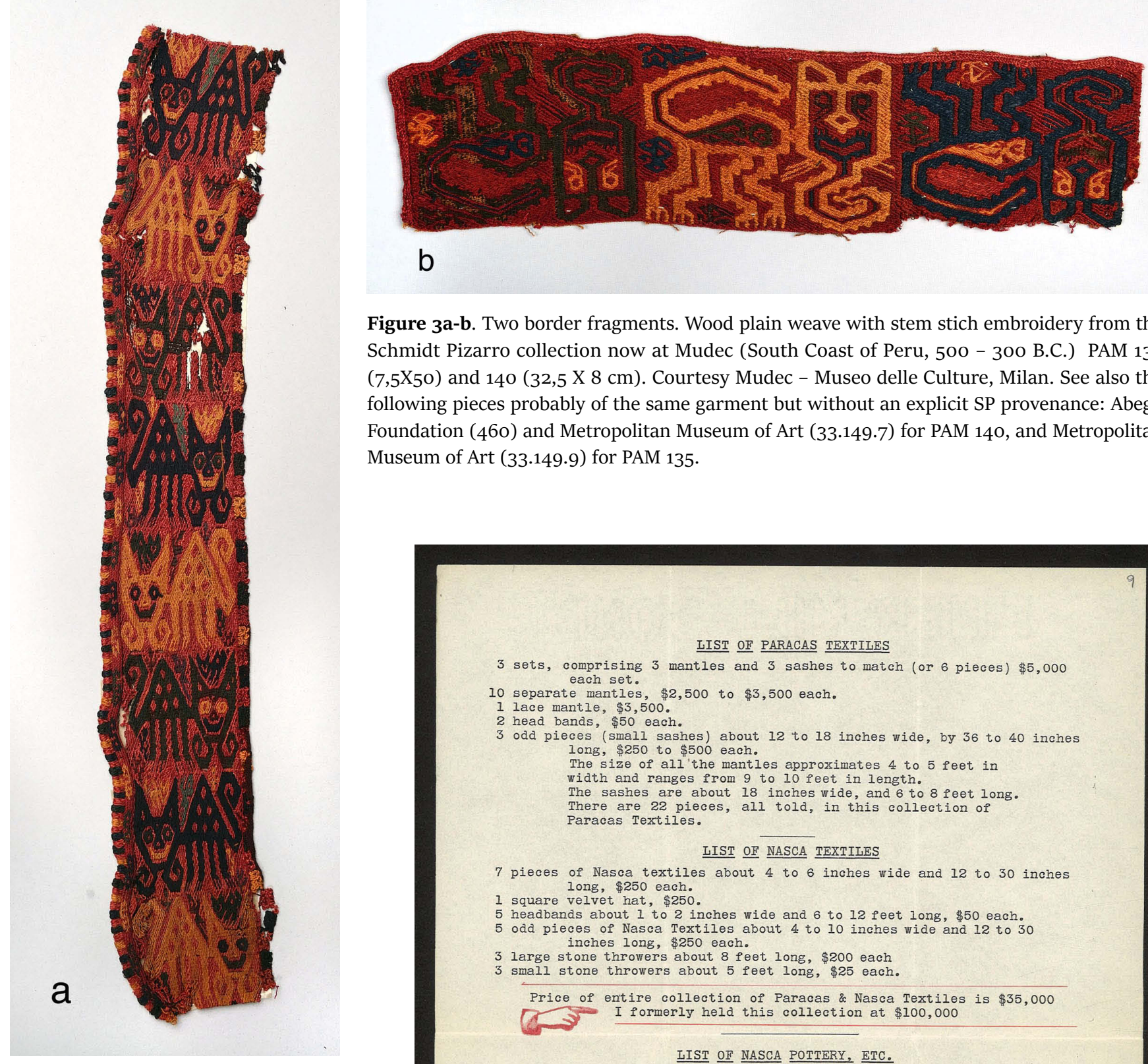

Figure 3a-b. Two border fragments. Wood plain weave with stem stich embroidery from the Schmidt Pizarro collection now at Mudec (South Coast of Peru, 500 - 300 B.C.) PAM 135 $\left(7,5 X_{50}\right)$ and $140(32,5$ X $8 \mathrm{~cm})$. Courtesy Mudec - Museo delle Culture, Milan. See also the following pieces probably of the same garment but without an explicit SP provenance: Abegg Foundation (460) and Metropolitan Museum of Art (33.149.7) for PAM 140, and Metropolitan Museum of Art (33.149.9) for PAM 135.

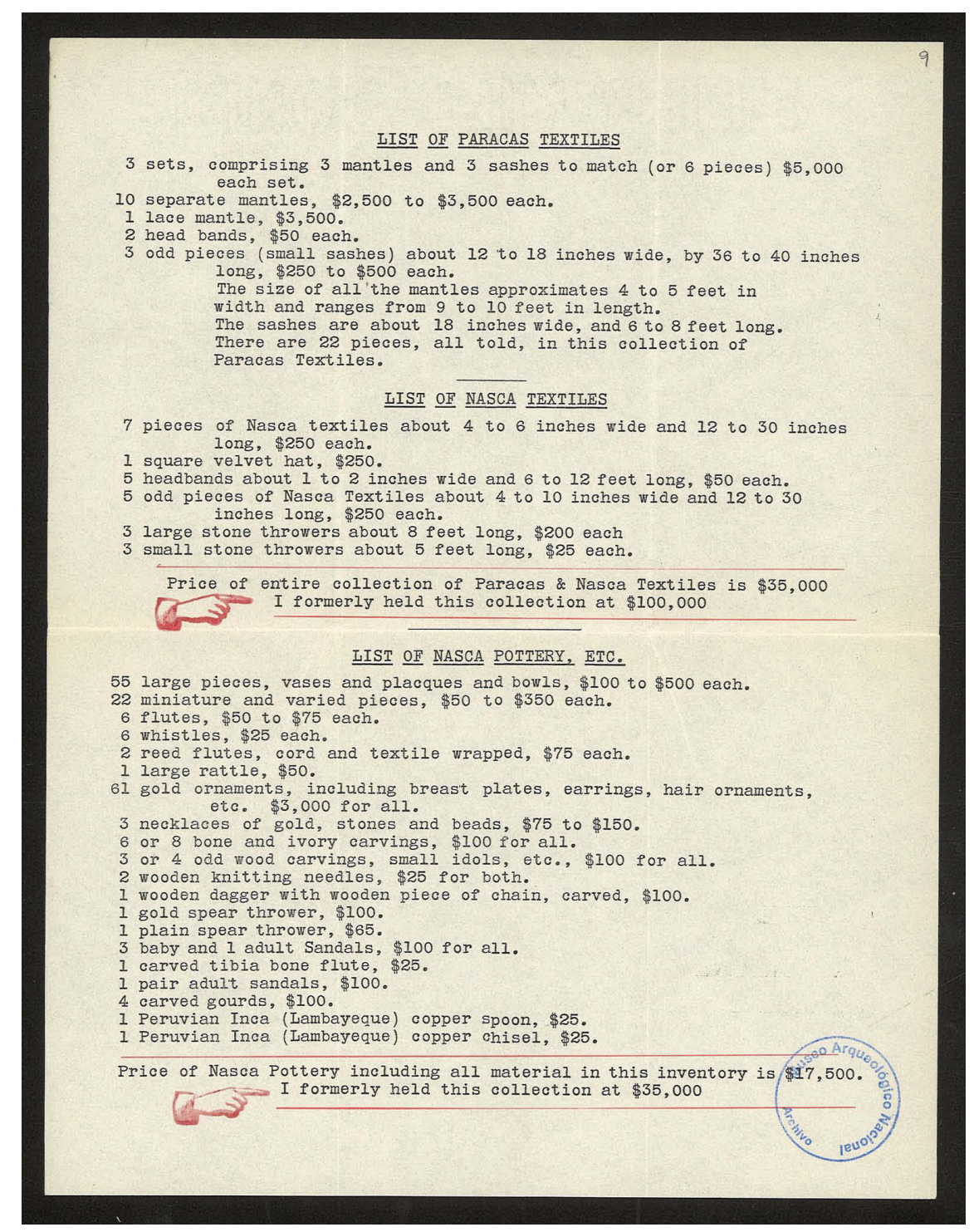

Figure 4. Price list of the Schmidt Pizarro collection around 1930. Courtesy Museo Arqueológico Nacional, Madrid. 
Probably starting from 1930 (until 1960), he began selling fabrics to George Hewitt Myers (1875-1957), founder of the Textile Museum in Washington DC, totaling 81 items sold. In August 1931, Schmidt Pizarro returned to the United States (passing through South America) where he began a lengthy negotiation for the sale of a lot of 30 objects to the Cleveland Museum of Art. In order to convince the conservator, Gertrude Underhill, ${ }^{33}$ of the purchase, he adopted a tactic that he also used later in many other cases: he left the objects on loan to the museum. Of the 30 objects, he managed to sell only two, and only after an extended correspondence with the conservator that ended years later in $1935 .{ }^{34}$

Between September and October 1931, he sold a batch of 12 textiles to the Boston Museum of Fine Arts. ${ }^{35}$ On April 12, 1932, he returned to New York after passing through Peru once again, explaining to Underhill that he had gone to retrieve "the last lot of the pre-Inca collection" 36 to be sold in the United States and in European museums. He referred to the Peruvian decree adopted on May $15^{\text {th }}$ of the same year, stipulating that it would be very difficult to take archaeological works out of the country. In effect, the Decree Law No. 7212 of 2 July $1931^{37}$ made the removal of archaeological objects from the country arduous, and forbidden in the case of a unique object, one for which the Peruvian government has no information regarding equivalent objects. Schmidt Pizarro continued to mention this law, sending it to senior officials of the institutions with which he was in contact in order to solicit the purchase of the works that were part of his collection until 1934 (fig. 5).38

Apparently, between 1932 and 1939,39 Schmidt Pizarro returned to Peru for just three months in 1934. At this point, we must ask ourselves where the collection - that he continued to sell in Europe for an entire decade - was stored. The most plausible hypothesis is that the works were already outside Peru, in the United States or in Europe, simply loaned to several museums or auction houses waiting to be sold, or alternatively in cases that Schmidt Pizarro

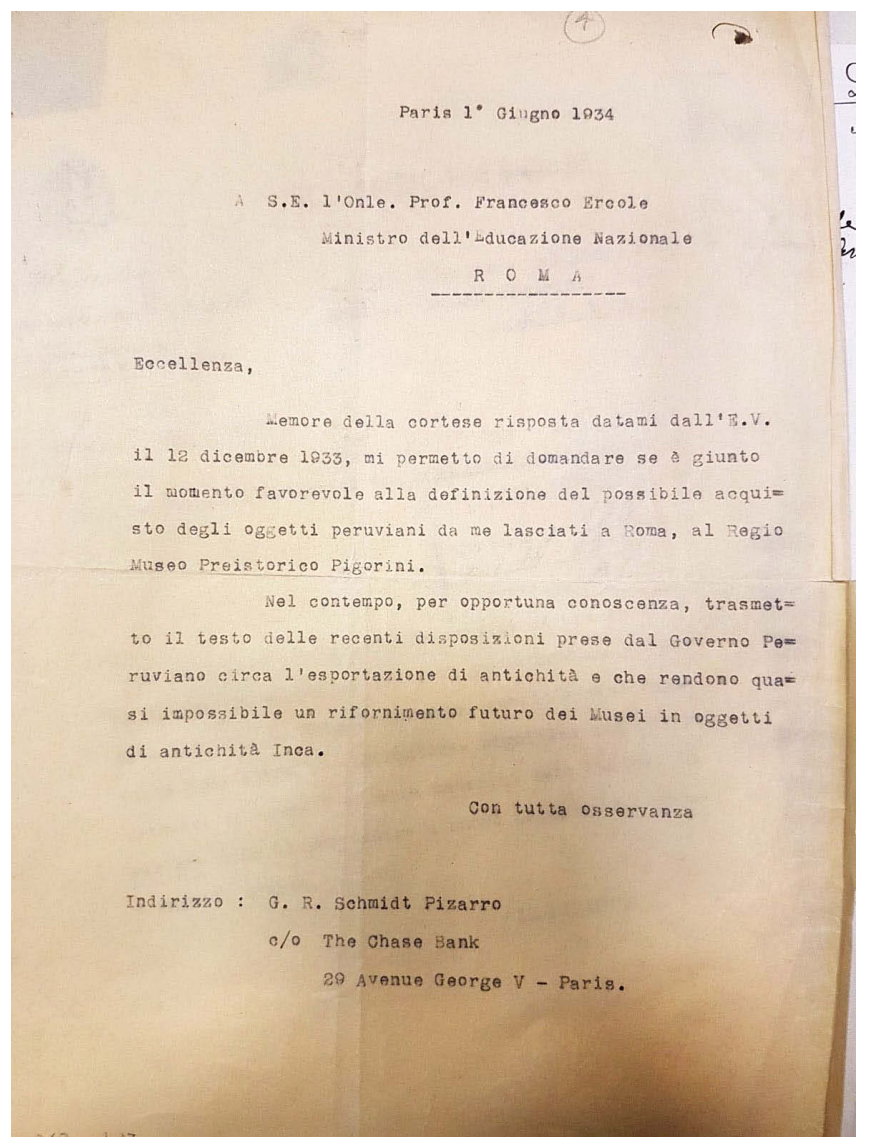

Figure 5. Letter from Schmidt Pizarro to the Italian minister Francesco Ercole (1st June 1934), where Schmidt Pizarro refers to the new Peruvian laws to convince him to buy a selection of objects from his collection for the Pigorini Museum suggesting that, from then on, it would have been very difficult to take archaeological works out of the country. Courtesy MuCiv Museum Archives, Rome. Photo Carolina Orsini.

carried with him. We know that he left objects for up to ten years for review at museums (e.g. at the Brooklyn Museum, where the loan with the purpose of assessing the purchase took place in various stages beginning April 23, $1932^{4^{\circ}}$

32. Archivo Museo Arqueológico Nacional, file 107 -1930- / 10.

33. Gertrude Underhill (1874 - 1954). Conservator for the textile section of the Cleveland Museum of Art since 1917, contributed significantly to the development of her section for the museum (Milliken 1954, pp. 115 - 116).

34. The conservator adduces as a justification that the museum was much involved in the bankruptcy of two US banks that occurred that same year. This is no. 1933.392, described as a "Pachacamac fish" [Ychsma fish appliqué] and 1933.393, described as a "Nasca tied and dyed piece" [Wari tie-dyed fragment] at the Cleveland Museum of Art. Letter of January 1, 1934 from Underhill to Schmidt P., CMA Archives.

35. We know that the textiles purchased were 16, Inv. 31.369 a - b and 31.699 - 31.710 sold on September 3, 1931 and Invv. 31,900 -31,901 sold on October 15, 1931. Boston Museum of Fine Arts website.

36. The same information is in another letter from Schmidt Pizarro to Gertrude Townsend, curator of textiles at the Boston Museum of Fine Arts: April 14, 1932, (Boston Museum of Fine Arts, Archives, TXTI Box 9).

37. The decree is from the previous year and sets May of the following year as a deadline for export of all non-registered archaeological objects. 38. Letter from Schmidt Pizarro to Minister Francesco Ercole, June 1, 1934, 363 Folder, MuCiv Museum Archives. Rome.

39. 1939 was the year during which he left Europe to return only after the end of the war.

40. Report by Herbert Spinden to Isabel Roberts dated April 10, 1943. For the first lot (Invv. 34.549 - 34.581), it took until 1934 to sell the objects. 
although the actual sale was only executed in the late-forties, or at the aforementioned Cleveland Museum of Art). Sometimes it happened that Schmidt Pizarro even forgot objects in these institutions, as occurred with two metal works left in Milan. ${ }^{41}$

In the second part of 1932, he traveled to Europe and from the beginning of September his residence was in Paris c/o The Chase Bank, 29 Avenue George V. ${ }^{42}$

In 1933, the British Museum in London bought ten textiles and some pre-Hispanic bone objects. ${ }^{43}$ It is really likely that, in the same year, S.P. was in contact with the Victoria and Albert Museum: using some specimens with a clear provenance as a reference, we were able to identify four or six other textiles (inv. T.70, 72, 73 and 74 and T.71 and T.75) and three more in the year 1936 (T.119, 120, 121). The same can be said for the Museum of Archaeology and Anthropology in Cambridge, where he sold objects to different Directors between 1933 and 1935.

From Paris, Schmidt Pizarro kept in close correspondence with various European cities, continuing relations with the United States (as evidenced by copious correspondence with the Cleveland Museum of Art and the Brooklyn Museum). At the beginning of 1933, he launched into contact with the directors of Italian museums. He began with Rome by writing to the then Director of the Pigorini Museum, Ugo Antonielli. The first traces of this correspondence date to March 1933, when negotiations began with the museum for the sale of a lot of works that would eventually be left on loan at that institution on March 16.44

At the same time, perhaps on the occasion of an exhibition called “Arte Antica dell'America Latina” (see below) held in Rome, Schmidt Pizarro established contact with the management of the Castello Sforzesco, and more precisely with the curator, Giorgio Nicodemi. 45 The report attached to the purchase procedure is dated March 1st, in which Nicodemi mentioned a collection "offered by Mr. Guillermo Schmidt resident in Paris. They come from a collection that was gathered in Peru by German scholars around 1820, and of which a part is kept in some German Museums." ${ }^{6}$ The collection is the one corresponding to the general inventory number IG 2281. It consists of, for the most part, the objects that were on display in Rome. The sale of this lot for 50oo Lire ended in March $1934 .{ }^{47}$ Concurrently, Schmidt Pizarro was negotiating a further lot of 14 objects (IG 2279), for which the report attached to the deed of sale mentions that the collection had been assessed to be of value by Professor Guido Valeriano Callegari. ${ }^{48}$ After a correspondence, of which probably only the final stages remain, Nicodemi and Schmidt Pizarro agreed to the sale of the 15 items $^{49}$ for 5000 Lire and the purchase was authorized by the City government on 10 February $1934 \cdot{ }^{50}$ What one deduces from the deeds is that these purchases were aimed at initiating the Castello Sforzesco collection of "pre-Hispanic antiquities"51 that, at the time, evidently began to arouse some interest, as is also evidenced by the Rome exhibition.

In 1933, the Castello d'Albertis of Genoa bought eight textiles (C.A. 1690-91-92) and two collars (C.A. 1693-1695), while in the following year it bought 24 ceramics (C.A. 16411664). The last acquisition by this museum was in 1938: five textiles (C.A. 1483-1488) and one collar. At the same time, the negotiations with Rome ended in September 1934 for 17 objects, including 11 textiles for 9000 Lire. ${ }^{52}$

The Brooklyn Museum Archives, Director [02]. File \# 117. Spinden, Herbert J. (o1 / 1939-12 / 1943).

41. Giorgio Nicodemi to Schmidt Pizarro, January 29, 1935, Issue 49/1937 Education Division, Citadel of the Archives (Cittadella degli Archivi) of the City of Milan.

42. CMA Archives, letter Schmidt Pizarro-Underhill of September 27, 1932. Following the same logic, his contact residence in New York was The Anglo South American Trust Co., 49 Broadway.

43. British Museum, catalog numbers: Am1933, - 5/6/7/8/9; Am1933, - 10.a/b/c/d/e; Am, 1933, - 11.a/b/c/d; Am1933, - 12; Am1933, - 13.

44. Letter from Schmidt Pizarro to Antonielli, dated September 23, 1934. 363 Folder, MuCiv Museum Archives, Rome.

45. Probably through Callegari. Both taught at the Università Cattolica del Sacro Cuore University in Milan.

46. Deed executed by Nicodemi in the file 166/1934 at the Citadel of the Archives (Cittadella degli Archivi) of the City of Milan.

47. Resolution of the City government dated March 10, 1934, contained in the dossier 166/1934 Education Department, kept at the Citadel of the Archives (Cittadella degli Archivi) of the City of Milan.

48. Dossier 175/1934 Education section, kept at the Citadel of the Archives (Cittadella degli Archivi) of the City of Milan. Born in Verona, Guido Valeriano Callegari (1896 - 1954) was among the first in Italy to approach the study of pre-Hispanic cultures, particularly in relation to Mexico and studies on astronomical knowledge. He was the holder of the first chair of American Antiquities, from 1925 to 1935, and was very active in dissemination to the general public. He made several study trips to Mexico (Venturi F. 1989).

49. Inventory numbers: PAMooo98-99, PAMooo47, PAMoooo7-8, PAMoooo1-05, PAMooo31-32, PAMo0114-164, PAMooo75, PAMooo13-15, PAMooo85, PAMooo26-29, PAMooo36-37, PAMo0166-167, PAMoo109-113a, b, c, d, e, f, PAMoo169-171. All objects are published in Laurencich - Aimi 1991.

50. Ibid. The same figure for two different lots of objects is not surprising: it is probably a stratagem to circumvent the spending limit imposed by Royal Decree 2839/1923, which is in fact mentioned in the resolution.

51. For a discussion of the formation of civic ethnographic collection, see Antonini-Orsini 2016.

52. Authorization issued by the Ministry of Education with Protocol 8885/1934, Directorate II of September 27, 1934, 363 Folder, MuCiv Museum Archives, Rome. 
In June 1934, Schmidt Pizarro left Italy and Europe for a period of about three months to return to Peru. ${ }^{53}$ In September he was back in Europe, where he also returned to Milan, and once again left a collection for examination by Professor Nicodemi. ${ }^{54}$ The negotiation for the acquisition of these objects continued until April 1935, but concluded only in 1937. The letters contained in the file related to this sale helped us to reconstruct the movements of these years, during which sales decreased.

We know that in 1935, 1937 and 1938, he sold a total of 19 textiles to the Montreal Museum of Fine Arts, 55 but we are still unable to verify if he visited that institution in person. In 1936, he was back in the US, this time in Miami: from there, he wrote to Gertrude Townsend of the Boston Museum of Fine Art (BMFA): "I so far have done well with the textiles I showed you, as I have sold the greater part to the museums in the West and here down in South." ${ }^{66}$ After a short break in New York, where he left some textiles to the Brooklyn Museum, ${ }^{57}$ he returned to Europe, in Budapest, "for business." ${ }^{8}$ In October 1936 , he finally met Gertrude Townsend and sold the textile registered as Boston MFA 36.625. After a short stay in Mexico, in March 1937 he was back in NY ready to go to Europe, ${ }^{59}$ where he landed on $22^{\text {nd }}$ of April. ${ }^{60}$

In 1937 he also sold to the Museum of Ethnology of Wien, now Weltmuseum Wien. ${ }^{61}$
At the end of 1937, he entered into an agreement for another sale at the Castello Sforzesco in Milan. ${ }^{62}$ In 1938, after having donated two gold plates to the same institution, ${ }^{63}$ he left (with a visa issued in Milan) to go to the United States, where sales promptly resumed. We have news of another sale or donation to the National Museum of Denmark in 1938. We have identified only one object, a paracas textile (inv. 0.5678), of which another fragment can be found in the Ethnological Museum (Ethnologisches Museum) of Berlin, with certified S.P. provenance. ${ }^{64}$

In that period the Cooper Union Museum for the Arts of Decoration (Smithsonian Institution, Washington) acquired a small amount of pre-Hispanic objects. ${ }^{65}$ The museum website shows one textile fragment (inventory number 1938 56 - 1 - a) depicting a stylized head: fragments of this same head are found in other collections. In the same year, the Peabody Museum of Archaeology and Ethnology acquired two "Tihuanaco" and "Chimu" painted fabrics ${ }^{66}$ along with other seven objects ${ }^{67}$ thanks to a gift of A. Tozzer, T. Barbour and D. Scott (the objects were selected by Samuel K. Lothrop). ${ }^{68}$ In May 1938, Schmidt Pizarro donated a preHispanic object ${ }^{69}$ to the National Museum of the American Indian in Washington.

At the end of 1938, Schmidt Pizarro was in Italy again, in Naples $7^{70}$ and later in Rome: his name appeared with a visa issued in the capital on passenger manifests of the ship

53. Letter from Schmidt Pizarro to Piero Barocelli dated December 3, 1934, 363 Folder, MuCiv Museum Archives, Rome. There is no evidence in passenger manifests of this trip.

54. These are the objects belonging to the General Inventory IG 2840, which will be acquired in 1937. Giorgio Nicodemi (1891-1967) was Superintendent of the Civic Museums of the Castello Sforzesco beginning in 1926. With this position he took care of the new set-ups of several rooms of the Castle, including the oriental and ethnographic sections in the Rocchetta del Castello Sforzesco, greatly expanding the collections with an acquisition campaign that took place between the 1920's and 1930's.

55. Erell Hubert, personal communication April 2019.

56. Schmidt Pizarro to Gertrude Townsend, March 5, 1936 Townsend (Boston Museum of Fine Arts, Archives, TXTI Box 9). So far, we have not identified these textiles, nor the museums involved.

57. Letter from Spinden to Roberts I., April 10, 1943. The Brooklyn Museum Archives, Director [02]. File \# 117. Spinden, Herbert J. (01 / 193912 / 1943).

58. Schmidt Pizarro to Townsend, May 12, 1936 (Boston Museum of Fine Arts, Archives, TXTI Box 9). We still do not know if that "business" was related to antiques or not.

59. These movements are traced in Boston MFA correspondence (Boston Museum of Fine Arts, Archives, TXTI Box 9).

6o. Southampton port passengers' list.

61. Barbara Poenighaus-Matuella, personal communication, March 2019.

62. Lot IG 2911, taken in charge on February 20, 1938.

63. Lot IG 2926, taken in charge on April 8, 1938.

64. Lena Bjerregaard, personal communication, April 2019.

65. Chronicle of the Museum for the Arts of the Cooperation Union works of art received by the museum; January - December $31,1939$.

66. Inventory numbers: 38-51-30 / 1696 and 38-51-30 / 1695.

67. Inventory numbers: $38-51-30 / 1988-1996$.

68. Inv. 38-51-30 / 1696 and 38-51-30 / 1695. Letter from S. Lothrop to Alfred Tozzer, May 17, 1938 (X File 38-51, Peabody Museum of Archaeology and Ethnology at Harvard Archives).

69. National Museum of the American Indian, catalog number 18/2877.

70. Letter from Schmidt Pizarro to Herbert Spinden, November 29, 1938. The Brooklyn Museum Archives, Director [02]. File \# 117. Spinden, Herbert J. (01 / 1939-12 / 1943). 
Vulcania, departing from Gibraltar and arriving in New York on March 22, 1939. This is interesting because at that time, a formality requested by US immigration was the listing of an acquaintance, and Schmidt Pizarro entered Count Pablo Mimbela ${ }^{71}$, consul of the embassy of Peru to the Holy See. This name confirms his attendance in diplomatic and ecclesiastical circles. Also, on this occasion, he had probably passed through Milan and had managed to sell a last lot of objects to Castello Sforzesco. ${ }^{72}$

Hence, he returned definitively to America, certainly also because of changing geopolitical conditions (Europe was now on the threshold of World War II). There, Schmidt Pizarro continued his activity as a salesman to American museums. Already in 1938, he had resumed correspondence with the Brooklyn Museum of Art's curator of Arts of the Americas, Herbert Spinden, ${ }^{73}$ and the director, Laurence Roberts, a correspondence that began with the previous director Philip Youtz in 1934. From an interesting report by the curator Spinden to the acting director, Isabel Roberts, ${ }^{74}$ we learn that after the first lot delivered in 1934, in 1935, 1936, and 1939, Schmidt Pizarro left 61 pieces (8 textiles and other works made of metal) on loan at the Brooklyn Museum. In 1941, Spinden claimed to have purchased other fragments for 1,318 US dollars directly from our antique dealer in Peru. In 1942, by way of the Stendhal Art Gallery, the museum acquired other pieces from the Schmidt Pizarro collection: these are probably two colonial objects ${ }^{75}$ with an inventory number referring to that year. Of the pieces left on loan in '35, '36, and '39, only three textiles were purchased in $1946 .{ }^{7}$ Schmidt Pizarro's relationship with the Brooklyn Museum was certainly not limited to sales negotiations. The Schmidt Pizarro pieces remained on loan for almost twenty years, in part because of the disruption of WWII, practically becoming part of the permanent collection. ${ }^{77}$ Contacts between Guillermo Schmidt Pizarro, Herbert Spinden and the director Roberts were quite frequent in the 40's. This correspondence, aimed only in part at the conclusion of the purchases begun in the 30's, tells us about the life of our antique dealer during and after World War II, when access to Europe was precluded to him.

In the meantime, as anticipated, pieces of the Schmidt Pizarro collection remained on loan at the Brooklyn Museum. In 1947, in a letter to Spinden dated November $16^{\text {th }}$, Schmidt Pizarro solicited the return of his collection to his homeland. On December $5^{\text {th }}$, Spinden declared himself willing, even if the operation would be quite burdensome for the museum (some of the works were on exhibit). On December $10^{\text {th }}$, Schmidt Pizarro agreed to leave the items on loan, probably still hoping to sell them. The correspondence was interrupted in 1951 when Schmidt Pizarro authorized the loan of a famous colonial tapestry for the exhibition "2000 Years of Tapestry Weaving. A Loan Exhibition” (Hartford, December 7, 1951 - January 27, 1952; Baltimore, February 27 - March 25, 1952). ${ }^{78}$

In Lima, where he apparently lived in that period with more stability than before, he continued his activity as art seller and dealer, with a greater interest in colonial art. In 1942 he participated in the Show of Virreinal art. ${ }^{79}$ On March 24, 1948, he donated 22 painted textiles to the Museo Nacional de Arqueología, Antropología y Historia del Perú (National Museum of Archeology and Anthropology) in Lima. The news of the donation confirms the position that Schmidt Pizarro held until a few years before as "Director de Industrias del Ministerio de Fomento."8o

We were able to follow the tracks of our man through a newspaper article in the Cuban newspaper Diario de la Marina: Schmidt Pizarro, defined as "experto en arte", traveled with the brother of the Peruvian president, Miguel

71. The name Mimbela (this time Mrs.) also appears as a member of the board of honour of the 1933 exhibition in Rome.

72. Lot IG 3258, taken in charge on March 18, 1940. Negotiations might have begun the previous year.

73. Herbert Spinden (1879 - 1967) was born in South Dakota. After earning a Ph.D. at Harvard, he was conservator in the anthropology section of the American Museum of Natural History in New York from 1909 until 1921. Later curator of the Mexican sections of the Peabody Museum and the Buffalo Museum of Science, in 1929 he was employed at the Brooklyn Museum. From 1935 to 1950, he was head of the Primitive Art department. He published numerous essays on Maya culture (Guide to the Records).

74. Letter from Spinden to Roberts I., April 10, 1943. The Brooklyn Museum Archives, Director [02]. File \# 117. Spinden, Herbert J. (o1 / 193912 / 1943).

75. A portable altar (Inv. 42.54) and a rug with coat of arm (Inv. 42.56) Provenance: Purchased in February 1942 from G. Schmidt and Pizarro, Bank of London and South America, NY for $\$ 100$.

76. The objects are as follow: a fragment of nasca-huari fabric (Inv. 46.46.1); a fragment of huari fabric with llama (Inv. 46.46.2) and a fragment of late nasca fabric (Inv. 46.46.3).

77. An undated list from a document of the Brooklyn Museum Archives entitled “Object offered on sale / Purchased by museum 1951 - 1952" lists the showcases where the pieces, marked with the letter L (lend), were exhibited on the permanent itinerary. The Brooklyn Museum Archives, Director [02]. File \# 117. Spinden, Herbert J. (01 / 1939-12 / 1943)

78. On page 86 of the catalogue, the famous colonial tapestry sold then to Metropolitan Museum was published.

79. Exposición de cuadros y objetos de arte virreinal realizada en los salones de la sociedad "Entre nous" del 2 al 14 de febrero de 1942.

8o. Donaciones 1948, p. 192. 
Bustamante Rivero to Italy where they were received by the Pope on July 17, 1948. It is reported that before visiting Rome, the illustrious travelers had passed through Spain, where they would return by plane. ${ }^{81}$ His presence in Europe is also confirmed by passenger manifests: on April $12^{\text {th }}$ from Callao to New York, on May $4^{\text {th }}$ he arrived in Southampton from New York, bound for France. According to records, he left Europe from Genoa on August $30^{\text {th }}$ of the same year. In this period, he contacted the Swiss Foreign Affair Museum, as he was trying to bring the colonial art show over to Europe. ${ }^{82}$

In 1950, he was in touch with Raoul D'Harcourt again, after a hiatus of nearly 20 years: he had found out that a piece he had left on loan at the Musée du Trocadero (de l'Homme from 1937) had never actually been paid. ${ }^{83}$ In the meantime, his brother Oscar sold 917 objects from Chile, Africa and Oceania to the Hamburg Museum in $1951 .{ }^{84}$ We do not know about Oscar's collection in detail, but it is also during those years that he obtained a role in diverse public offices as chair of the Colegio de Contadores Públicos de Lima. ${ }^{85}$

In 1951 Guillermo participated in the opening of the $R i$ etberg museum in Zurich selling them 20 pieces. ${ }^{86}$ Probably in the same years he got in touch with the Gestaltung museum (also located in Zurich) (18 pieces registered between 1951 and 1958, maybe one or two pieces passed to the Rietberg, and two that had entered the collection much earlier, in 1934). ${ }^{87}$

The tracks of Schmidt Pizarro are lost until his next sale to the Musée du Cinquantenaire, today the Musées Royaux d'Art et d'Histoire in Brussels. Negotiations began in August 1953 with conservator Elisabeth della Santa and director Charles de Borchgrave d'Altena. From reconstructions of correspondence from the archives, the museum bought three different lots: the first in 1955, composed of three fragments of fabrics for 7,000 Belgian francs, ${ }^{88}$ the second in 1957 consisting of a quipu and a Tiahuanaco fabric for 12,00o Belgian francs, ${ }^{89}$ and the third in 1958 of another three fragments of fabrics for 20,000 Belgian francs. ${ }^{90}$

In the years 1955, 1956 and finally 1962, Guillermo sold a total of over 60 objects, again to the Weltmuseum Wien. ${ }^{91}$ During the 50's, he also managed to visit the textile center in Krefeld, Germany (probably in 1953), where he sold several fabrics that are yet to be precisely identified..$^{22}$

Other information that we have been able to gather regarding Schmidt Pizarro concerns the sale of a beautiful $17^{\text {th }}$ century carpet to the Metropolitan Museum of Art in New York (Accession Number: 56.163). This carpet, as mentioned earlier, had been on loan for many years at the Brooklyn Museum. In the same year, he sold another textile, perhaps Moche (Inv. 56.127), to the Brooklyn Museum.

Despite his very advanced age for the time, from documents kept at Musées Royaux d'Art et d'Histoire de Bruxelles, we learn that our antique dealer was still in Europe in 1958, when he went to the Musées Royaux d'Art et d'Histoire de Bruxelles to sign the last sale negotiated with this institution. ${ }^{93}$ In 1958 , he also sold three colonial shawls to the Metropolitan Museum of Arts of New York (Inv. 58.66.1-58.66.3).

As far as we are able to discern, the last letter he wrote dates to October $5^{\text {th }}, 1958$, in which Schmidt Pizarro asks for administrative clarifications in Brussels. ${ }^{94}$ Several pieces are found in the collection of the Museum der Kulturen (Museum of Cultures) in Basel, purchased in 1958 (IV c 9487 and 9489), and one piece (IV c 9580) bought in 1960; other

81. http://ufdc.ufl.edu/UFoooo1565/14126/22? search=schmidt+pizarro Consulted on December 18, 2018.

82. Alexander Brust, personal communication, March 2019.

83. Schmidt Pizarro to D'Harcourt, November 22, 1950, Archive du Muséum d'Histoire naturelle, 2 AM 1 K86e -1930-1950.

84. Christine Chávez, personal communication, December 2018.

85. Report by Oscar Schmidt Pizarro on participation in the sixth International Congress on Accounting, held in London in June 1952, as well as his visits to similar institutions in Scotland and West Germany. Opac library of the Universidad Católica de Lima and also of the Biblioteca Nacional de Lima.

86. RPB 1001 - 1002, 1011, 1103 - 1106, 1204 - 1205, 1303 a b c d, 1307, 1311, 1407, 1410, 1414, 1805.

87. 1951-1958: KGS1951-0036, KGS1951 0048 -0049, KGS1952 ooo6 -0013, KGS1952 0016, KGS1952 0019 - o020, KGS1952 o022, KGS1954 0049, KGS1958 0046 - 0047. 1934: KGS-09555 and KGS-09555_1

88. AAM 55 - 1, AAM 55 - 2, AAM 55-3.

89. AAM 57 - 2. AAM 57 - 3. This lot was originally composed of another Quipu and another fabric (note of September 8, 1956, D 4626/2 Archive Musées Royaux d'Art et d'Histoire de Bruxelles).

90. AAM 58 - 1, AAM 58 - 2, AAM 58 - 3. (Elisabeth della Santa to Borchgrave d'Altena, July 2, 1958, D 4793/8, Archive Musées Royaux d'Art et d'Histoire de Bruxelles).

91. Barbara Pönighaus-Matuella, personal communication, April 2019. Weltmuseum Wien may have been Schmidt Pizarro's top client during those years, but we have not yet accessed the archival documentation to confirm it.

92. Katalin Nagy, personal communication, March 2019.

93. Letter from Schmidt Pizarro to Della Santa of June 16, 1958 (D. 4626/21, Archive Musées Royaux d'Art et d'Histoire de Bruxelles). 94. Letter from Schmidt Pizarro to Borchgrave d'Altena, October 5, 1958 (D 4793/12, Archive Musées Royaux d'Art et d'Histoire de Bruxelles). 
sales would follow in $1961^{95}$ and in $1963 .{ }^{96}$ This was, at the time, his last known sale; considering that he passed away in January of 1964, we can safely say that he worked "till the very end", at the age of 83 .

We are aware of other sales in Munich, Frankfurt, Detroit, Saint Louis and at the Rhode Island School of Design, but we are still waiting for authorization to verify this information in the archives, as will be the case for further information that is bound to emerge throughout the next phase of the project.

\section{The Sales Strategy}

In all these years, Schmidt Pizarro seems to have acted according to a tried and true scheme. First of all, he implemented a sales strategy focusing on pre-selected areas, where he lived for extended periods. Establishing a direct acquaintance with persons was fundamental to him. After the first contacts by mail with museum directors or conservators, who were often introduced to him by a common acquaintance, it is understood that Schmidt Pizarro visited the museums with which he was dealing. On these occasions, in more than one case, he left objects "in vision" on loan, as already mentioned, even for several years. ${ }^{97}$

By doing this, he achieved two goals: on the one hand, he gained the trust of the prospective buyer, who could assess the objects without haste and decide at a later time whether or not to proceed with the purchase; on the other hand, he left the objects in public institutions, guarded by professionals worthy of the utmost trust, rather than carrying them around. In the case of the Brooklyn Museum, there was even a sort of management from the point of view of valorization, as we have seen, with objects on permanent display, which certainly constituted an increase in the personal prestige of the antique dealer.

As seen above, especially in the correspondence with Milan, Rome, Brussels, Brooklyn and Cleveland, the negotiations continued for years, on many different "fronts" active at the same time. Our antique dealer never seemed to lose the thread of the discourse, he recalled price proposals for decades and, apparently (except in the cited case of the plaques left in Milan), he was always aware of where his works were located. He certainly had an accurate inventory system and a topographic register of the pieces of his collection that initially must have included over 1,0oo objects.

Negotiations were slow, but inexorable; years later, with discretion, a final answer was asked about the pieces on loan. Often, when the transaction for a specific type of object was unsuccessful, he would propose others of different types (as in Brooklyn).

With a profile that we could almost define as psychological, in order to convince the buyer of the value of his pieces, he played mainly on the fact that it was an antique collection, as he said, belonging to his family; almost as if he were not a professional antique dealer, but simply a refined connoisseur. Archival sources indicate that he knew his way around the scholars' circles: he was acquainted with eminent figures such as Rafael Larco Herrera ${ }^{98}$ and, as previously mentioned, Raoul D'Harcourt and Samuel K. Lothrop, who considered him an esteemed connoisseur.

Schmidt Pizarro often mentions his preference for selling his family's collection to public museums so that the utmost care might be taken to assure the conservation of indigenous artifacts. This will be highlighted when - as seen above - he took on the position of Director de Industrias at the Ministerio de Fomento y Obras Públicas of Peru. It is in this period that he dedicated himself to organizing exhibitions of Peruvian art abroad and to publishing writings on this topic. ${ }^{99}$ But, in addition to his statements, we know that this antique dealer not only parceled out works to multiply his earnings, ${ }^{100}$ but he even often sold them to private collectors.

To give credit to his positive reputation, in several instances he donated pieces: this happened in Berlin, Paris, Milan, and at Washington's Smithsonian Institution. Moreover, in the early 1930's, as a strategy to induce acquisitions, he emphasized the Peruvian heritage protection laws

95. IVc 9676 - IVc 9679 and IVc 9684 - IVc 9686.

96. Rebozos IVc 9722 - IVc 9729.

97. The same strategy was adopted by other dealers of the same period (e.g. Stolper, see Fischer et al. 2017).

98. Schmidt Pizarro to Della Santa, letter of October 3, 1958 (D4626/21 Archive Musées Royaux d'Art et d'Histoire de Bruxelles). S.P. mentions Rafael Larco Herrera as "my friend".

99. For example, the article on the platería peruana published on Il_Mercurio on February 4, 1946. Document annexed to the letter of February 16 , 1946 sent by Schmidt Pizarro to Spinden (The Brooklyn Museum Archives, Director [02]. File \# 117. Spinden, Herbert J. (01 / 1939-12 / 1943). 100. Regarding the specimen 36.625 MFA of Boston: in the letter dated October 28, 1936, in an attempt to convince her to purchase, Schmidt Pizarro wrote to Gertrude Townsend that only two fragments of the textile existed, and that he had already sold the other piece to the "Gobelin Museum" in Paris. The following year, in a letter dated April 4, 1937, he admitted that he had another piece of the same textile in Lima, hoping that Townsend would decide to buy the "twin piece" of the object already sold to the MFA. These letters, together with others, prove that dividing or even cutting textile was a strategy. (The Boston Museum of Fine Arts, Archives, TXTI Box 9) 
recently enforced, sending, as in the case of Rome, a summary of the Decree Law 6643/1931 to prove that the purchase of Peruvian archaeological pieces would become increasingly rare in the future.

This is, briefly, the strategy Schmidt Pizarro followed with public institutions. We do not know how his negotiations with private individuals in the United States took place, nor do we understand his relationship with the European antique market.

\section{A circular relationship: exhibitions, markets, museums}

From the beginning, Schmidt Pizarro realized that a fundamental factor for sales was the "reputation" that his objects could earn by appearing in various public exhibitions. Paris was particularly important for this purpose: as we have already said, the 1930's were "Les années folles de l'ethnographie" (Delpuech et al., 2017). The market was at its peak at the time: the city was the Eldorado for trade in pre-Hispanic artefacts (Saint-Raymond and Vaudry 2018), peaking between 1927 and 1930. As the flow of works from South America increased, prices did not go down (SaintRaymond and Vaudry 2018). The market began to drop just as S.P. arrived in the French capital, only to regain strength in the years between ' 37 and ' 39 . In the 1930's, moreover, most of the South American artifacts on sale at the Hotel Druout were Andean (Saint Raimond Vaudry, 2018).

It is possible, therefore, that S.P. had been attracted and ultimately decided to settle in Paris - because of this circumstance, which was not fortuitous, but the result of a deep interest in non-European arts, established in Paris for at least two decades. As early as 1924, the "Latin American Art Exhibition" had been held at the Palais Galliera and, ten years earlier in 1914, the famous antiquarian Joseph Brummer had opened his gallery where he sold many important works of European and native art. Little by little, the preHispanic objects wound up in the sight of the antique dealers most tied to the world of the avant-gardes, and so the perceived value - cultural and economic - of these objects began to rise.

The consecration took place in 1928, when the exhibition Les Arts Anciens de l'Amerique was held at the Decorative
Arts Museum. Curated by George Henry Rivière, and with a catalogue prefaced by Raoul D'Harcourt, the exhibition displayed more than 1200 objects and influenced the taste of art dealers and buyers over the following years: the outstanding art dealer linked with Primitivist avant-gardes (La Porte - Dagen 2013) Charles Ratton (1895 - 1986) was one of the major private lenders. The relationships with the gray eminences of the South American art market in Paris are made clear in a correspondence exchange between Pizarro and Rivière, ${ }^{101}$ in a memorandum from Rivière regarding the S.P. collection: "Some pieces have already been sold in the United States and to Mr. Brummer, antiquarian. Report to Mr. D'Harcourt, then to Mr. Heye, ${ }^{102}$ then to Mr. Ratton." ${ }^{103}$ From another exchange, ${ }^{104}$ we learn that D'Harcourt acted as an intermediary between S.P. and Rivière, and also managed payments on behalf of S.P. In a letter, D'Harcourt asks Schmidt Pizarro to help him with his book, scouting unknown woven techniques and analyzing them from a technical perspective.

While the Paris exhibition took place before the appearance of S.P. on the Parisian scene, he in the meantime successfully managed to enter into the organization of a temporary exhibit in Italy, which, in its format and even in the title, had many similarities with the French one: the Ancient Art of Latin America exhibition held in Rome between May and June 1933 (fig. 5). ${ }^{105}$ The precious illustrated catalog mentioned objects from S.P. that later became the property of the Castello Sforzesco of the City of Milan, today at the Museo delle Culture. Some objects also appeared in popular publications of the time. ${ }^{106}$ The organizer of this pioneering enterprise for Italy, which displayed the preHispanic heritage of the museums of Rome, Milan, Genoa, Turin and Florence, was Guido Valeriano Callegari, a Mexican art expert who held the Chair of Pre-Hispanic Antiquities at the Università Cattolica del Sacro Cuore University in Milan: a pivotal character in the Italian negotiations of Schmidt Pizarro.

The Rome exhibition, as we have said, owed much to that in Paris: the works were selected for their "artistic value" and their expressive force (according to canons close to Primitivism, a movement that is recalled in various points of a newspaper article focusing on this exhibit by Antonielli, 1933), all enhanced by a minimalist setup that

101. Archive du Muséum d'histoire naturelle, 2 AM 1 K86e 1930-1950, "Visites. 18 Juillet 1930".

102. George Gustav Heye (1874-1957) was the founder of the Museum of the American Indian (MAI), Heye Foundation, of New York City, now his collections are held at the Smithsonian Institution. Heye became a client of S.P..

103. Charles Ratton (1895 - 1986) was one of Paris most important dealers in ethnographic objects, from the 20 's.

104. Archive du Muséum d'Histoire naturelle, 2 AM 1 K86e -1930-1950, "Lettre 10 Juillet 1931" D'Harcourt to S.P.

105. The exhibition catalog (General Management for Antiquities and Fine Arts, 1933) is a gold mine of information: with over 200 exhibits, the exhibition is probably one of the first moments in which pre-Hispanic archeology is promoted in Italy.

106. Callegari 1933, pp.779 - 796 
780 LE VIE D' ITALIA E DEL MONDO

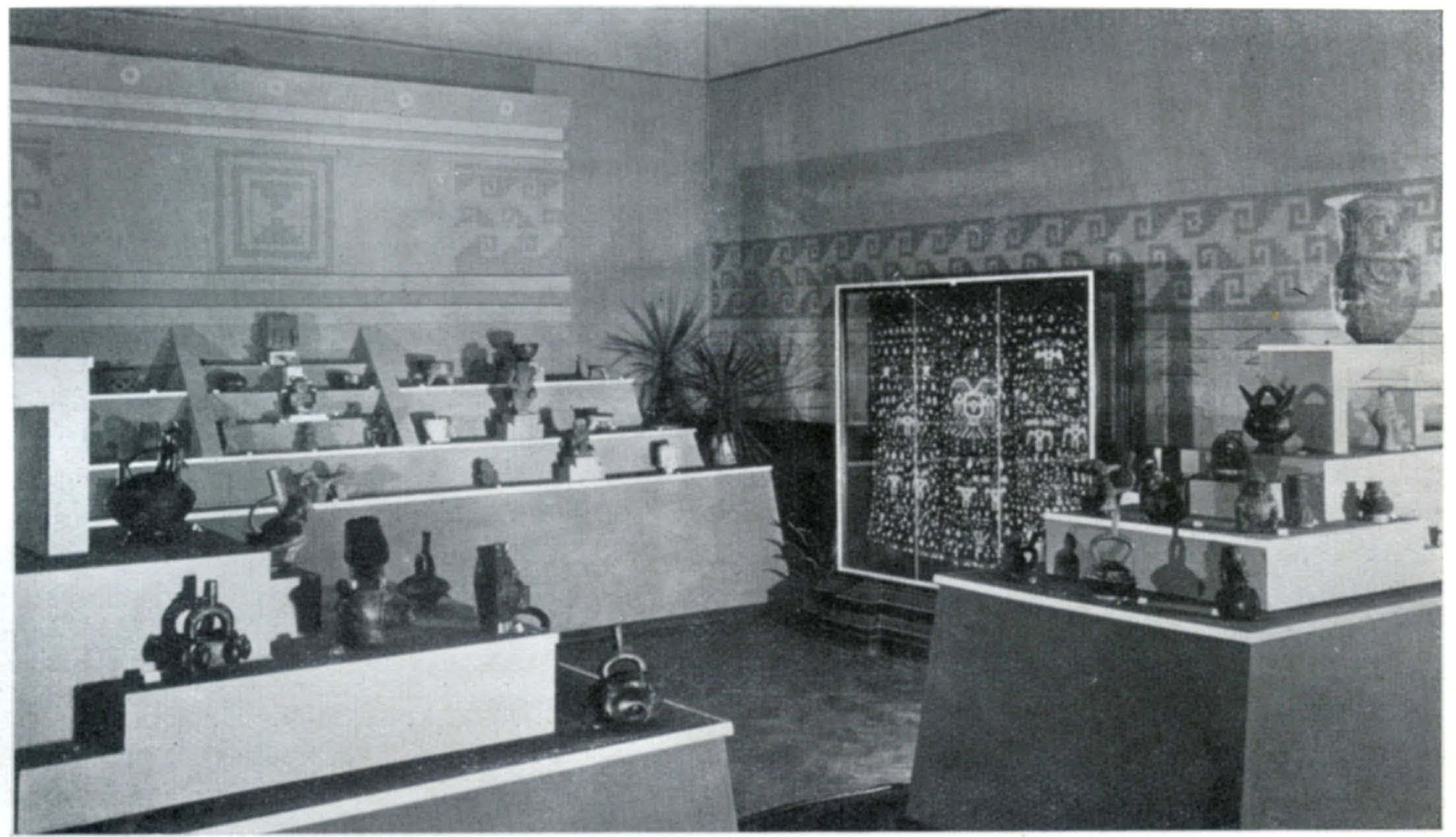

UNA SALA DELLA MOSTRA DI ARTE ANTICA DELl'AMERICA LATINA, IN ROMA In questa sala sono raccolti specialmente i cimeli provenienti dai Musei di Torino e di Roma.

Figure 6. One room of the exhibition Mostra d'arte antica dell'America Latina (Roma, 1933) where many objects from the Schmidt Pizarro collection were on display. Courtesy Touring Club Italiano, Milan.

respected aesthetic criteria similar to those of the Paris exhibition (ibid.).

A few years later, S.P. lent other works for a temporary exhibit of textiles to the Gobelin Manufacture in Paris (1935).

S.P.'s exhibition activity was also considerable in the United States: for decades, his objects appeared in various exhibits organized by the most important museums. First of all, the Brooklyn Museum: in 1939, some pieces were loaned to the exhibition "Masks: Barbaric and Civilized" (October 28, 1939 through January 1, 1940). Two other exhibitions followed, to which Schmidt Pizarro lent works: ${ }^{107}$ "Art Finds a Way" (November 1, 1940 through January 10, 1941), and "America South of U.S." (November 13, 1941 through January 2, 1942), where the colonial collection of our antique dealer was presented ${ }^{108}$ to the public and, finally, "Peruvian Costume, for the Living and the Dead", (October 11, 1946 through February 9, 1947). ${ }^{109}$ In the meantime, in 1942, in Lima, S.P. contributed substantially to the "Exposición de cuadros y objetos de arte virreinal" held in the premises of the company "Entre nous" (February 2-4, 1942).

At a certain point, S.P. was not content with simply lending his works to exhibitions, but became the organizer himself. A very interesting newspaper article ${ }^{110}$ - of which we

107. Brooklyn Museum Archives. Records of the Department of Public Information. Press releases, 1939 - 1941. o9-10 / 1939, 255-7. Not having been able to personally consult the archives, it is not possible to cite the pieces that are actually exhibited.

108. Collecting colonial and "modern" objects was the new trend in S.P. taste after WWII: "In the last year with patience I had collected plenty and very interesting material of early colonial, republican and modern folklore things". Letter from Schmidt Pizarro to H. Spinden of February 16, 1946. The Brooklyn Museum Archives, Director [02]. File \# 117. Spinden, Herbert J. (01 / 1939-12 / 1943).

109. Fane D. 1996: 187, describing a hat from the colonial era of the Brooklyn Museum (41.1275.103), quoting from a letter from Schmidt Pizarro to Herbert Spinden in which Schmidt offers a description of this type of headgear and its function: "Caps that the caciques of the villages near Cuzco used, in the time of the Inquisition, when they presided at court (tribunal). Each village had a different ...” 110. The Brooklyn Museum Archives, Director [02]. File \# 117. Spinden, Herbert J. (01 / 1939-12 / 1943) 
are unable to identify the heading - informs us that in 1946 Schmidt Pizarro organized an "Exposición de Arte Peruana" during the "Semana Peruana" in Viña del Mar (a renowned seaside resort) in Chile as a former member of the Fine Arts Council of Lima and recently retired from the role of Head of the Peruvian Manual Industries Department within the Ministerio de Fomento.

In 1948, he contacted several European institutions to organize a tour of Peruvian colonial art exhibitions in Europe. This entailed very intense activity, considering shortly after the umpteen loans to the traveling exhibition on textiles held between Hartford and Baltimore in the years 1951-52. ${ }^{11}$

As said above, from the 1940's onwards, Schmidt Pizarro began to introduce new objects dating from the colonial and republican period to the market, beginning a new phase in his life as an art dealer, perhaps aware of the fact that archaeology could no longer be exported. ${ }^{112}$ He considered this collecting trend as an innovation, a harbinger of great possibilities, despite the difficulty in procuring the objects to which high-ranking families were still attached. ${ }^{113}$ It is also thanks to his work as an indefatigable promoter of Peruvian craftsmanship, which undoubtedly allowed him to come into contact with different areas of traditional production, that the typology of artifacts now available to him seemed more varied, ranging from silverware to tapestries and furniture, without neglecting textiles. The role of S.P. is also made clear in the magazine Foreign Commerce Weekly, where he is cited as organizer of an exhibition of "manual" industries held in Lima in $1944^{114}$ and also as the promoter of many activities related to the recovery of traditional "Indian skills" (1944: 2).
He definitely found support in Spinden thanks to the exhibition "America South of U.S." (Brooklyn Museum of Art, 11.13.1941 - 01.02.1942), in which the colonial objects of the Schmidt Pizarro collection were given great prominence. ${ }^{115}$ The exhibition was promoted as the first of its kind where the value of Spanish America art was specifically highlighted. It can therefore be said that S.P. really did contribute to spreading and enhancing Peruvian manufactures, in compliance with his tasks at the Ministerio de Fomento, with the added benefit of increasing the market value of his colonial/republican collection.

It is no coincidence that his sales of colonial/republican objects from that moment surged: in addition to the sale of colonial objects to the Brooklyn Museum in 1946, we recall the sale of a colonial papelera to the Museo de América (Madrid) in 1957, the sales to the Metropolitan Museum in New York in 1958, and finally, the sale of republican ethnographic objects in Basel in the years 1958, 1961 and 1963.

Another interesting path, which will have to be investigated in the future, is the link between S.P. and Morris De Camp Crawford, journalist for "Women's Wear Daily”, Fairchild editions, and pre-Hispanic textile expert for the American Museum of Natural History in New York. ${ }^{116}$ Crawford and Spinden, as has recently come to light, were among the "inventors" of an American fashion style ${ }^{117}$ between the 1920's and 1930's in New York. Schmidt Pizarro probably played a role as an expert of pre-Hispanic textiles in the program conceived by Spinden and Crawford entitled "Designed in America" (1916-1922) (Whitley 1998), and the establishment at the Brooklyn Museum of a "Study Room" ${ }^{118}$ certainly made pre-Hispanic fabrics

111. “200o Years of Tapestry Weaving. A Loan Exhibition” (Hartford, December 7, 1951 - January 27, 1952; Baltimore, February 27 - March 25, 1952).

112. Although we know that he continued to sell archaeological objects throughout the 1940s and 1950s, as evidenced by sales in Switzerland and Brussels for example. Note that many pre-Hispanic objects of these last sales are fragments of objects previously seen: perhaps unsold stock from the pre-war period.

113. Letter from Schmidt Pizarro to Spinden, January 27, 1942. The Brooklyn Museum Archives, Director [02]. File \#117. Spinden, Herbert J. (01/1939-12/1943)

114. Foreign Commerce Weekly, vol. XVII, no. 9, p.11.

115. The director of the National Museum of Anthropology of Lima, Luis E. Valcarcel (1891-1987), stated in the report of his study trip to the United States in the winter of 1941, "In Brooklyn, I found new pieces such as: two magnificent mantles of Spanish-Indian art (which we called "gobelinos" from Cuzco), probably from the $16^{\text {th }}$ century; one of them has this annotation on the card: "Donation by Mr. Guillermo Schmidt Pizarro" [...] finally, another fabric (32-229-L), also given by Schmidt Pizarro, which is an extremely rare piece, with symbolic representations: you see flames and other animals in an embryonic state, inside the body of a monster" Valcarcel 1943, p. 290.

116. Morris De Camp Crawford (1882 - 1949) Journalist and researcher at the American Natural History Museum who published several manuals on pre-Hispanic and in particular Peruvian textiles. In both 1936 and 1938 Schmidt Pizarro declared his residence in New York as care of M.D.C. Crawford c/o Fairchild Editions (Ellis Island passenger manifest: Ship Hamburg 1936, October 9 and 1938, March 23rd). Together with Spinden, Mead and Wissler, Crawford was one of the promoters of the "Designed in America" program, aimed at stimulating the creation of an American style based on Native American artifacts (Whitley L. 1998).

117. Tartsinis 2013, exhibition catalog An American style: Global Sources for New York Textile and Fashion Design, 1915 -1928.

118. In 1918, Stewart Culin (curator of the BMA), in collaboration with Crawford of the American Museum of Natural History, opened a Study Room with ethnographic clothing and textiles to inspire contemporary artists and designers (see above). 
fashionable, a fact that probably also influenced the antiquarian market.

Through his activity as a vendor, S.P. therefore influenced not only the art market and the taste of museum directors, but also those who dealt with manufacturing at that time, as well as the intellectual environment, which in turn set the standards on art purchases in a restricted circle of buyers that included both public and private players.

And what were the objects "worthy" of being purchased, according to Schmidt Pizarro? It is still premature to formulate a definitive hypothesis because, as already mentioned, the process aimed at identifying S.P.'s pieces in museums around the world is still ongoing, but from the cases analyzed it is possible to hypothesize that Paracas textiles, which had appeared on the market in the decade before S.P. began his business, had a certain importance in the commercial proposals he formulated. ${ }^{119}$

\section{Final Reflections: Schmidt Pizarro and the Taste for Collecting pre-Hispanic Artefacts in the First Half of the $\mathbf{2 0}^{\text {th }}$ Century}

Considering the scattered nature of the studies of the antiquarian market of pre-Hispanic objects, it is difficult to make a comprehensive evaluation of S.P.'s influence on the evolution of taste for collecting these materials, but here we offer a few reflections. Between the early 1900 and the 1950s, an enormous quantity of Andean artefacts arrived in Europe and in the United States, e.g. the Theodor Wilhelm Gretzer (1847-1926) (Bjerregaard 2016; Daggett 2012: note 98), Eduard Gaffron (1861-1931) (Daggett 2012: note 96), and Mariano Macedo (1823-1894) (Gänger 2014a) collections: thousands of objects that suffered the same fate of scattering and fragmentation as the S.P. collection.

As already theorized by Guinchard and Savoy (2018), the colonial expansion in the nineteenth century caused an increase in demand and supply on the western market for objects from different cultures of the world. This created new "occupations," with many intermediaries contributing locally to the configuration of global markets and the mass dispersal of pre-Hispanic objects in the western world.
Among them, a small group of antique dealers were the ones who, with their taste, greatly influenced the supply and demand system of these objects. We could define them as "percipience makers" (and "prestige makers", we would add) regarding these artifacts, as was already theorized for the African art market of the same years (Biro 2018).

"Taste" is a subjective element and is not connected to the historical importance of an object. It can be built from scratch. The first exhibitions of South American art in Europe were based on the taste of just a few individuals, including various traders. S.P. tried from the beginning to be credited by them as another "percipience makers" both in Paris and in the United States: Joseph Brummer, Raoul D'Harcourt, Charles Ratton are the outstanding names with whom S.P. entered into more or less close relationships aimed at building a network of key individuals with whom he could redistribute his works. This mechanism highlighted quite recognizable and homogeneous objects, a narrow range of types, that are now found in different museums of the world.

The world of Andean art dealers and intermediaries such as S.P. have only recently been the object of studies and we are convinced that research into the personal stories of these "percipience and prestige makers" may mark a step forward in studies on provenance.

Through a mix (today ethically unacceptable ${ }^{120}$ ) of public service, private interests and genuine interest in native cultures, Schmidt Pizarro (and his colleagues) contributed in his own way to the spreading of knowledge about the material culture of the Andean world and its aesthetics. However, summarizing his activity, we must conclude that through the practice of indirect support to clandestine excavations, cutting of fabrics and dispersion of objects on the art market, the balance of his work cannot but be considered absolutely negative.

The archaeology of the Andes is a young discipline: in its beginnings, characters like S.P. played a key role in the formation of the collections that have been later studied by both native and foreign scholars. In the future, there will be a lot of work to do to unravel the biographies and modus operandi of these fundamental but little known intermediaries that, for better or for worse, are part of the history of Peruvian archaeology.

119. This was the area that was gaining great fame thanks to the findings in the necropolis of the Paracas Peninsula made by the pioneer of Peruvian archaeology Julio C. Tello (made public in the congress of the Americanists of Rome in 1926). Paracas became as famous as Pachacamac and Ancón near Lima; two areas where, next to the activity of tomb raiders or huaqueros, systematic work had also begun a few years earlier (Rowe 1954: 6 et passim and Kaulicke 1997:14-15). These sites had given shape to the large collections that characterized Lima of the late Nineteenth century (Gänger 2014b:7-8), and Pizarro, too, always boasted finds from Ancón and Pachacamac in his lists, besides objects from the southern coast.

120. In the past, the attitude was completely different. Museum specialists, as we previously said, cut off textiles in order to trade them with other museum. The emphasis was more on having the more complete range of different types of objects for documenting the "technological level" achieved by native populations instead of having a complete object in order to reconstruct its function and contest (see Bjerregaard 2001). 


\section{Acknowledgments}

Prior to this research, published works about Guillermo Schmidt Pizarro were almost nonexistent. Researches in Peru have been carried out by our colleague and friend Federica Villa, who examined archival sources about the Schmidt Pizarro family. A special thanks goes to Susan Bergh and Amanda Mikolic, who provided the detailed list of letter exchanges with the Cleveland Museum that served as a basis to trace S.P.'s movements through Europe and the United States. An impressive number of important documents is also preserved in the Brooklyn Museum archive: Nancy Rosoff, Molly Seegers and Georgia de Havenon opened a virtual window in those archives for us, and worked hard and selflessly on the draft revision. Victòria Solanilla Demestre believed in this research project right from the beginning and supported us enthusiastically. A great help was offered us by Giulia Bugada, a volunteer with Servizio Civile Nazionale (Civil Service Program) at Museo delle Culture di Milano, who assisted us in organizing sources and connecting various S.P. objects across online museum collections around the world.

The global nature of this study would have been impossible without the help of many colleagues, to whom we express our deepest gratitude. In Europe: Belgium: Serge Lamaitre (Musées Royaux d'Art et d'Histoire, Bruxelles); Denmark: Lena Bjerregaard (The Danish National Research Foundation's Centre for Textile Research, Copenhagen); France: Paz Nuñez and Emanuela Canghiari (Musée du Quai Branly, Paris); Germany: Manuela Fischer (Ethnologisches Museum, Berlin), Christine Chávez (Markk - Museum am Rothenbaum, Hamburg), Katalin Nagy (Deutsches Textilmuseum, Krefeld); Italy: Maria Camilla de Palma (Museo Castello D’Albertis, Genoa), Mario Mineo (Muciv-Museo delle Civiltà, Rome), Tommaso Bonfanti (Cittadella degli Archivi, Milan); Spain: Aurora Ladero Galán (Museo Arqueológico Nacional, Madrid); Switzerland: Alexander Brust (Museum der Kulturen, Basel), Peter Fux and Esther Tisa (Rietberg, Zurich), Sabine Flaschberger and Julia Klinner (Museum für Gestaltung, Zurich); United Kingdom: Clothworkers' Centre for the Study and Conservation of Textiles \& Fashion (London), Jason Cooper and James Hamill (The British Museum, London), Imogen Gunn (Museum of Archaeology and Anthropology, Cambridge). All the archival materials located in London have been checked by Gabriella Primi.

In North America: Canada: Erell Hubert (the Montreal Museum of Fine Arts); United States: Sumru Aricanli, Mary Lou Murillo, Kristen Mable (American Museum of Natural History, New York), Jennifer M. Swope (Boston Museum of Fine Arts), Nancy Rosoff, Georgia de Havenon and Molly Seegers (Brooklyn Museum of Arts), Laura Costello
(Peabody Museum of Archaeology and Ethnology, Harvard), Ann Pollard Rowe (The Textile Museum, Washington D.C.), Amy Clark (Saint Louis Art Museum). Ann Peters helped to identify some Paracas textiles and provided information about other Peruvian collectors.

\section{Online Catalogs and Resources}

H. Allen Anderson. Pratt, George Dupont; http://www. anb.org/articles/20/20-00818.html; American National Biography Online, Feb. 200o. Access Date: January 7, 2019

Informe de Oscar Schmidt Pizarro sobre la participación en el sexto Congreso Internacional de Contabilidad, realizado en Londres en junio de 1952, así como de sus visitas a instituciones similares de Escocia y Alemania Occidental. Biblioteca Universidad Católica de Lima.

\section{References Cited}

Antonielli, Ugo

1933 Arte primitiva d'America. Una grande mostra romana. L'Italia letteraria IX (20), May 14, 1933.

Antonini, Anna and Carolina Orsini

2016 A Brief History of Collections. In Museum of Cultures. Objects of Encounters. Catalogue of Works and Exhibit Guide, Carolina Orsini and Anna Antonini (eds.), pp.18-31. Il Sole 24 Ore, Milan.

Bernal Multon, Vanessa

2018 Formation des collections archéologiques et ethnographiques: notes sur des trajectoires d'objets latino-américains. Les Cahiers de l'École du Louvre, Recherches en histoire de l'art, histoire des civilisations, archéologie, anthropologie et muséologie 12:1-25. DOI:10.400o/cel.878, accessed May 22, 2019.

Biro, Yaëlle

2018 Fabriquer le regard: marchands, réseaux et objets d'art africains à l'aube du XXe siècle. Les presses du reel, Dijon.

Bjerregaard, Lena

2001 Doubletten - puzzles that could maybe someday be reconstructed. Baessler-Archiv, band 49, Berlin.

2016 Lambayeque-Style Textiles in the Ethnologisches Museum, Berlin. Nuevo Mundo Mundos Nuevos. DOI: 10.400o/nuevomundo.6929o, accessed May 27, 2019.

Brennan, Christine E.

2015 The Brummer Gallery and the Business of Art. Journal of the History of Collections 27(3):455-468. DOI 10.1093/jhc/fhuo44, accessed May 22, 2019. 
Brooklyn Museum

Guide to the Records of the Department of the Arts of Africa, the Pacific Islands, and the Americas, p.11. The Brooklyn Museum, New York.

Callegari, Guido V.

1933 Arte dell'America Latina. Le Vie d'Italia e del Mondo. Rivista del Touring Club italiano 7:779-796.

Daggett, Richard E.

2012 An Annotated Tello-Centric History Of Peruvian Archaeology, Volume One, (ca.1825-1925). Manuscript published online and accessed May 27, 2019.

Delpuech, André, Laurière, Christine and Christine Peltier-Caroff (eds.)

2017 Les années folles de l'ethnographie: Trocadero 2837. Publication scientifiques du Museum National d'Histoire Naturelle, Paris.

Direzione Generale Antichità e Belle Arti

1933 Mostra d'arte antica dell'America Latina: Roma, 4 maggio-3o giugno 1933 XI. Officine dell'Istituto Poligrafico dello Stato, Rome.

Exposición de cuadros y objetos de arte virreinal

1942 Exposición de cuadros y objetos de arte virreinal, realizada en los salones de la sociedad "Entre nous" del 2 al 14 de febrero de 1942. Talleres de la Compañía de impresiones y publicidad E. Bustamante y Ballivián, sucesor, Lima.

Fane, Diana (editor)

1996 Converging Cultures: Art \& Identity in Spanish America. Brooklyn Museum Bookshop, New York.

Faucourt, Camille

2017 L'annonce d'une renaissance: l'exposition les Arts anciens de l'Amerique. In Les années folles de l'ethnographie: Trocadero 28-37, André Delpuech, Christine Laurière \& Christine Peltier-Caroff (eds.), pp.51-77. Publication scientifique du Museum National d'Histoire Naturelle, Paris.

Fischer, Manuela; Röhrs, Stefan; Gómez-Sánchez, Elena; Pausewein, Regine-Ricarda; Born, Hermann; Reiche, Ina and Kai Engelhardt

2017 Product of the art market? The representation of silver corncobs at the Ethnologisches Museum in Berlin. Bulletin IFEA 46 (1): 291-305. DOI: https:// doi.org/10.400o/bifea.8301

Foreign Commerce Weekly

1944 Peru Is Expanding Manual Industries. Foreign Commerce Weekly 17 (9): 12 and 41.

Gänger, Stefanie

2014a Conversaciones sobre el pasado. Nuevo Mundo Mundos Nuevos. DOI:10.400o/nuevomundo.67124, accessed May 27, 2019. 2014b Relics of the Past. The Collecting and Study of PreColumbian Antiquities in Peru and Chile, 1837-1911. Oxford University Press. Oxford.

Gosden, Chris and Yvonne Marshall

1999 The Cultural Biography of Objects. World Archaeology 31(2):169-178. DOI 10.1080/o0438243.1999.9980439, accessed May 22, 2019 .

Hill, Kate

2012 Introduction: Museum and Biographies. Telling Stories about People, Things and Relationships. In Museums and Biographies: Stories, Objects, Identities. Heritage Matters Vol.9, edited by Kate Hill, pp.1-10. Boydell \& Brewer, Woodbridge.

Hoerll, Alberto

1910 La colonización alemana en Chile. In Los Alemanes en Chile, Sociedad científica alemana de Santiago (ed.), pp.1-62. Imprenta Universitaria, Santiago del Chile.

Kaulicke, Peter

1997 Contextos funerarios de Ancón. Esbozo de una síntesis analítica. Pontificia Universidad Católica Fondo Editorial, Lima.

Kopytoff, Igor

1986 The Cultural Biography of Things: Commoditization as Process. In The Social Life of Things, Arjun Appadurai (ed.), pp.64-91. Cambridge University Press.

La Porte, Sophie and Philippe Dagen

2013 Charles Ratton. L’invention des Arts «Primitifs». Skira, Milan.

Laurencich Minelli, Laura and Antonio Aimi

1991 Museo d'Arti Applicate. Raccolta Precolombiana. Musei e Gallerie di Milano. Mondadori Electa, Milan.

Milliken, William

1954 Gertrude Underhill (1874-1954). The Bulletin of the Cleveland Museum of Art 41(6):115-116.

Museo Nacional de Antropología y Arqueología

1948 Donaciones y decomisos. Revista del Museo Nacional de Antropología Arqueología 2(1):192.

Peltier-Caroff, Carine and Claudia De Sevilla

2016 Les objets de l'exposition Les arts anciens de l'Amerique, 1928: de nouvelles sources iconographiques et documentaire. Le revue des Musées de France 3:82-111.

Pilar, Vega F.

1933 Tejidos peruanos procedentes de la Colección de los Señores Schmidt y Pizarro de Lima. Nota descriptiva. [Adquisiciones en 1930]. Museo Arqueológico Nacional, Madrid. 
Rowe, John H.

1954 Max Uhle, 1856-1944: A Memoir of the Father of Peruvian Archaeology. University of California publications: American Archaeology and Ethnology Vol. 46(1). University of California Press.

Saint-Raymond, Léa and Élodie Vaudry

2018 A New Eldorado. In Acquiring Cultures: Histories of World Art on Western Markets, Bénédicte Savoy, Charlotte Guichard and Christine Howald (eds.), pp.101-120. De Gruyter, Berlin.

Tello, Julio C.

1926 Los descubrimientos del Museo de Arqueología Peruana en la Península de Paracas. Atti del XXII Congresso Internazionale degli Americanisti I:679690, Roma.

Thebele, Winani

2018 Depatriated objects. A reflection. In Acquiring Cultures: Histories of World Art on Western Markets, Bénédicte Savoy, Charlotte Guichard and Christine Howald (eds.), Bénédicte Savoy, Charlotte Guichard and Christine Howald (eds.), pp.9-14. De Gruyter, Berlin.
Valcarcel, Luis E.

1943 De mi viaje a los Estados Unidos. Revista Iberoamericana VI(11):271-296. DOI:https://doi. org/10.5195/reviberoamer.1943.1108, accessed May 22th, 2019.

Venturi, Franco

1989 Guido Valeriano Callegari, professor of American antiquities. Civiltà veronese II(IV):76-78.

Wadsworth Atheneum and Baltimore Museum of Art

19522000 Years of Tapestry Weaving: A Loan Exhibition. Wadsworth Atheneum Hartford, Dec. 7, 1951 to Jan. 27, 1952. The Baltimore Museum of Art, Feb.27, 1952 to Mar.25, 1952. Wadsworth Atheneum, Hartford.

Weil, Stephen E.

1999 From Being about Something to Being for Somebody: The Ongoing Transformation of the American Museum. Daedalus 128(3):229-258.

Whitley, Lauren D.

1998 Morris De Camp Crawford and the "Designed in America” Campaign, 1916-1922. Proceedings of the Sixth Biennial Symposium of the Textile Society of America, 215:410-419. New York. 